\title{
Crystalline phase analysis and phosphorus availability after thermochemical treatment of sewage sludge ash with sodium and potassium sulfates for fertilizer production
}

\author{
Hannes Herzel ${ }^{1}$ (D) $\cdot$ Zeynep Aydin $^{1} \cdot$ Christian Adam ${ }^{1}$
}

Received: 28 March 2021 / Accepted: 25 August 2021 / Published online: 15 September 2021

(c) The Author(s) 2021

\begin{abstract}
Phosphorus rich sewage sludge ash is a promising source to produce phosphorus recycling fertilizer. However, the low plant availability of phosphorus in these ashes makes a treatment necessary. A thermochemical treatment $\left(800-1000{ }^{\circ} \mathrm{C}\right)$ with alkali additives transforms poorly plant available phosphorus phases to highly plant available calcium alkali phosphates $(\mathrm{Ca}, \mathrm{Mg})(\mathrm{Na}, \mathrm{K}) \mathrm{PO}_{4}$. In this study, we investigate the use of $\mathrm{K}_{2} \mathrm{SO}_{4}$ as additive to produce a phosphorus potassium fertilizer in laboratory-scale experiments (crucible). Pure $\mathrm{K}_{2} \mathrm{SO}_{4}$ is not suitable as high reaction temperatures are required due to the high melting point of $\mathrm{K}_{2} \mathrm{SO}_{4}$. To overcome this barrier, we carried out series of experiments with mixtures of $\mathrm{K}_{2} \mathrm{SO}_{4}$ and $\mathrm{Na}_{2} \mathrm{SO}_{4}$ resulting in a lower economically feasible reaction temperature $\left(900-1000{ }^{\circ} \mathrm{C}\right)$. In this way, the produced phosphorus potassium fertilizers $(8.4 \mathrm{wt} . \% \mathrm{~K}, 7.6 \mathrm{wt} . \% \mathrm{P})$ was highly plant available for phosphorus indicated by complete extractable phosphorus in neutral ammonium citrate solution. The added potassium is, in contrast to sodium, preferably incorporated into silicates instead of phosphorus phases. Thus, the highly extractable phase $(\mathrm{Ca}, \mathrm{Mg})(\mathrm{Na}, \mathrm{K}) \mathrm{PO}_{4}$ in the thermochemical products contain less potassium than expected. This preferred incorporation is confirmed by a pilot-scale trial (rotary kiln) and thermodynamic calculation.
\end{abstract}

Keywords Phosphorus recovery $\cdot$ Recycling fertilizer $\cdot$ Calcium alkali phosphate $\cdot$ Silicate

\section{Introduction}

Phosphorus (P) and potassium (K) are essential elements for all life forms, and thus main compounds of fertilizers. The supply of raw materials to produce $\mathrm{K}$ bearing fertilizers is classified as uncritical because of large $\mathrm{K}$ deposits around the world and K recovery from the ocean [1]. This is different for $\mathrm{P}$. Conventional $\mathrm{P}$ fertilizers are based on phosphate rock. These deposits are located in a few countries [2]. Europe has negligible deposits and depends nearly completely on imports [3]. Thus, countries in Europe are searching for other $\mathrm{P}$ sources [4]. Sewage sludge ashes (SSA) which are currently mainly landfilled $[5,6]$ are prominent alternative resources for $\mathrm{P}$ fertilizer production. P-rich SSA contains up to 12 wt.\% $\mathrm{P}$ in Germany [5]. Recovery of $\mathrm{P}$

Hannes Herzel

herzelhannes@gmail.com

1 Bundesanstalt für Materialforschung und -Prüfung (BAM), Unter den Eichen 87, 12205 Berlin, Germany from suitable SSA types that are rich in $\mathrm{P}$ and low in pollutants (10,900 t/a P based on Krüger and Adam [5]) could substitute more than $10 \%$ of imported conventional fertilizers in Germany $(86,100$ t/a P based on Industrieverband Agrar [7]). The P recovery from SSA and other waste streams from wastewater treatment will become mandatory in Switzerland [8] and in Germany [9]. A direct application of SSA as fertilizer is avoided because it contains heavy metals which are partly above limit values of fertilizer legislation [10] and the plant availability of $\mathrm{P}$ is low [11]. Phosphorus in the SSA is mainly bonded in the crystalline phase whitlockite type $\left(\mathrm{Ca}_{3-\mathrm{x}}(\mathrm{Mg}, \mathrm{Fe})_{\mathrm{x}}\left(\mathrm{PO}_{4}\right)_{2}\right)$ [12] a poorly plant available $\mathrm{P}$ phase [13]. Thus, $\mathrm{P}$ recovery technologies target recycling fertilizers that comply with fertilizer legislation and contain highly plant available $\mathrm{P}$ phases.

Thermochemical treatment of SSA is a promising method to produce highly plant available $\mathrm{P}$ fertilizers and to reduce the content of toxic heavy metals [4, 10]. This process transforms the poorly plant available $\mathrm{P}$ from whitlockite and $\mathrm{AlPO}_{4}$ to highly plant available calcium alkali phosphates due to thermochemical reactions with alkali additives 
such as sodium sulfate $\left(\mathrm{Na}_{2} \mathrm{SO}_{4}\right)$ in the temperature range $800-1000{ }^{\circ} \mathrm{C}[14,15]$. Previous plant growth studies confirmed that this product has plant availability comparable to triple super phosphate [16, 17]. The plant availability of $\mathrm{P}$ can be estimated using the chemical extraction in neutral ammonium citrate, calculated as a fraction $\left(\mathrm{P}_{\mathrm{NAC}, \text { rel }}\right)$ of the total P-content [11].

The thermochemical treatment was successfully demonstrated on technical scale using $\mathrm{Na}_{2} \mathrm{SO}_{4}$ as additive during a pilot trial in 2014 [10]. The maximal $\mathrm{P}_{\mathrm{NAC}, \text { rel }}$ value of 80 wt.\% was satisfying to use this material for greenhouse pot experiments and a field trial [18].

In general, the formed calcium alkali phosphate is the crystalline phase $\mathrm{CaNaPO}_{4}[10,14]$. Current studies postulate that calcium could be partly substituted by $\mathrm{Mg}$ $[15,19-21]$ and forms a phosphate phase comparable to $\mathrm{Ca}_{13} \mathrm{Mg}_{5} \mathrm{Na}_{18}\left(\mathrm{PO}_{4}\right)_{18}$ [22].

Compared to sodium $(\mathrm{Na})$ containing additives, the thermochemical treatment with K-containing additives is rarely investigated. The addition of K-containing additives could be used to produce a PK- or NPK-fertilizer. The additional costs for the more expensive $\mathrm{K}$ additives might be compensated by the value of $\mathrm{K}$ in the fertilizer. Potassium hydroxide $(\mathrm{KOH})$ [23] and potassium carbonate $\left(\mathrm{K}_{2} \mathrm{CO}_{3}\right)$ [24] were successfully tested to convert $\mathrm{P}$ compounds to highly plant available $\mathrm{CaKPO}_{4}$. Potassium sulfate $\left(\mathrm{K}_{2} \mathrm{SO}_{4}\right)$ could be also a suitable additive because it is a by-product of biofuel production [25] and can be available at a reasonable price. However, first investigations at $1000{ }^{\circ} \mathrm{C}$ with $\mathrm{K}_{2} \mathrm{SO}_{4}$ as an additive showed that the reaction of the phosphate phases with $\mathrm{K}_{2} \mathrm{SO}_{4}$ is not complete due to its high melting point of $1070{ }^{\circ} \mathrm{C}$ [10]. To reduce the melting point of the additive, $\mathrm{K}_{2} \mathrm{SO}_{4}$ can be mixed with $\mathrm{Na}_{2} \mathrm{SO}_{4}$. The composition $3 \mathrm{Na}_{2} \mathrm{SO}_{4} * \mathrm{~K}_{2} \mathrm{SO}_{4}$ has the lowest melting point $\left(823{ }^{\circ} \mathrm{C}\right)$ in this system [26].

The added Na or K-containing additives react with phosphates as well as with silicates. The reaction with silicates is thermodynamically favored and takes place first. Thus, at first alkali aluminosilicates are formed and later calcium alkali phosphates. Depending on silicon (Si) and P contents of SSA, a certain fraction of the alkali additive is consumed for the reaction with silicates and must be taken into account for total additive dosing and thus additive costs for the process [14].

In this study, we focus on the possibilities to partly substitute the alkali additive $\mathrm{Na}_{2} \mathrm{SO}_{4}$ by $\mathrm{K}_{2} \mathrm{SO}_{4}$ to increase the content of the valuable nutrient $\mathrm{K}$ in the recycling fertilizer. Processing with different ratios of $\mathrm{Na}_{2} \mathrm{SO}_{4} / \mathrm{K}_{2} \mathrm{SO}_{4}$ was investigated in laboratory-scale experiments (crucible trials) as well as in pilot-scale trials in a rotary kiln. The thermochemical products are evaluated by analyzing extractable $\mathrm{P}$ as well as by crystalline phase analysis. The formation of phases is compared with thermodynamic calculations.

\section{Materials and methods}

\section{Materials}

Sewage sludge ash for laboratory scale calcination experiments and the demonstration trial was taken from an industrial mono-incineration facility in Germany that was already investigated in a SSA monitoring project [5]. Dried sewage sludge (SS) originating from a large-scale wastewater treatment plant in Germany was pulverized to a particle size $<500 \mu \mathrm{m}$ for muffle furnace experiments. Elemental compositions of SSA and SS are displayed in Table 1. $\mathrm{Na}_{2} \mathrm{SO}_{4}$ and $\mathrm{K}_{2} \mathrm{SO}_{4}$ (technical grade) was acquired from Cordenka GmbH \& Co KG Obernburg, Germany and from company Kemira, Finland, respectively.

\section{Laboratory scale calcination experiments}

The set up for laboratory crucible trials was similar to Herzel et al. [10] and Stemann et al. [14]. SSA was mixed with dry $\mathrm{SS}$ as a reducing agent in a weight ratio 5 to 1 . This mixture of SSA and SS was mixed with milled $\mathrm{Na}_{2} \mathrm{SO}_{4}$ and/or $\mathrm{K}_{2} \mathrm{SO}_{4}$ (vibrating cup mill made of tungsten carbide, Siebtechnik $\mathrm{GmbH}$, Mühlheim/Ruhr, Germany) targeting on a molar ratio $(\mathrm{Na}+\mathrm{K}) / \mathrm{P}$ of $2 \mathrm{~mol} / \mathrm{mol}$. This molar ratio was chosen
Table 1 Average elemental composition of sewage sludge ash (SSA), sewage sludge (SS) and of one selected thermochemical product of each series at reaction temperature required for high $\mathrm{P}_{\mathrm{NAC} \text {,rel }}$ displayed in wt.\% with standard deviation (in triplicates)

\begin{tabular}{lrlrrrrr}
\hline \multicolumn{1}{c}{ SSA } & SS & CT-Na-1000 & CT-K25-1000 & CT-K50-1000 & CT-K75-1050 & CT-K100-1150 \\
\hline $\mathrm{Al}$ & $6.7 \pm 0.5$ & $0.8 \pm 0.1$ & $6.2 \pm 0.1$ & $5.9 \pm 0.2$ & $6.4 \pm 0.1$ & $5.9 \pm 0.2$ & $5.7 \pm 0.1$ \\
$\mathrm{Ca}$ & $11.4 \pm 0.8$ & $3.8 \pm 0.1$ & $9.0 \pm 0.1$ & $9.3 \pm 0.4$ & $9.6 \pm 0.1$ & $9.9 \pm 0.4$ & $8.3 \pm 0.1$ \\
$\mathrm{Fe}$ & $5.9 \pm 0.3$ & $7.5 \pm 0.2$ & $4.8 \pm 0.3$ & $4.8 \pm 0.2$ & $4.8 \pm 0.1$ & $4.7 \pm 0.2$ & $5.1 \pm 0.1$ \\
$\mathrm{~K}$ & $1.5 \pm 0.1$ & $0.2 \pm 0.1$ & $1.1 \pm 0.1$ & $4.7 \pm 0.3$ & $8.4 \pm 0.2$ & $11 \pm 0.6$ & $13.5 \pm 0.2$ \\
$\mathrm{Mg}$ & $1.6 \pm 0.1$ & $0.4 \pm 0.1$ & $1.2 \pm 0.1$ & $1.3 \pm 0.1$ & $1.5 \pm 0.1$ & $1.3 \pm 0.1$ & $1.2 \pm 0.1$ \\
$\mathrm{Na}$ & $0.5 \pm 0.1$ & $0.2 \pm 0.1$ & $10.8 \pm 0.4$ & $10.6 \pm 0.3$ & $6.5 \pm 0.1$ & $4.8 \pm 0.1$ & $0.5 \pm 0.3$ \\
$\mathrm{P}$ & $9.4 \pm 0.3$ & $4.2 \pm 0.1$ & $7.2 \pm 0.3$ & $7.6 \pm 0.2$ & $7.6 \pm 0.1$ & $7.3 \pm 0.2$ & $7.2 \pm 0.1$ \\
$\mathrm{~S}$ & $0.9 \pm 0.1$ & $0.9 \pm 0.1$ & $2.7 \pm 0.1$ & $3 \pm 0.2$ & $1.6 \pm 0.1$ & $1 \pm 0.2$ & $1.4 \pm 0.4$ \\
$\mathrm{Si}$ & $11.4 \pm 0.8$ & $3.1 \pm 0.4$ & $8.9 \pm 0.3$ & $9.9 \pm 0.1$ & $9.8 \pm 0.3$ & $9.8 \pm 0.5$ & $9.4 \pm 0.4$ \\
\hline
\end{tabular}


to achieve complete extractability in neutral ammonium citrate $\left(\mathrm{P}_{\mathrm{NAC}, \mathrm{rel}}\right)$ as shown in a previous study by Herzel et al. [10]. Experiments with additive mixtures of molar ratios of $\mathrm{K}_{2} \mathrm{SO}_{4}$ and $\mathrm{Na}_{2} \mathrm{SO}_{4}$ were labelled CT-Na (Crucible trial with $\left.\left.\mathrm{Na}_{2} \mathrm{SO}_{4}\right), \mathrm{CT}-\mathrm{K} 25\left(\mathrm{Na}_{2} \mathrm{SO}_{4} / \mathrm{K}_{2} \mathrm{SO}_{4}\right)=75 / 25\right)$, CT-K50 $\left(\mathrm{Na}_{2} \mathrm{SO}_{4} / \mathrm{K}_{2} \mathrm{SO}_{4}=50 / 50\right), \mathrm{CT}-\mathrm{K} 75\left(\mathrm{Na}_{2} \mathrm{SO}_{4} / \mathrm{K}_{2} \mathrm{SO}_{4}=25 / 75\right)$ and CT-K100 $\left(\mathrm{Na}_{2} \mathrm{SO}_{4} / \mathrm{K}_{2} \mathrm{SO}_{4}=0 / 100\right)$. The $\mathrm{Na}_{2} \mathrm{SO}_{4} /$ $\mathrm{K}_{2} \mathrm{SO}_{4}$-mixtures were pre-processed and homogenized by heating at $600{ }^{\circ} \mathrm{C}$ over night and subsequent milling in a vibrating cup mill before utilization in the thermochemical trial.

10-13 $\mathrm{g}$ of the above described mixtures of SSA, SS and alkali additive were calcined in crucibles of $75 \mathrm{~mL}$ volume. The material mixtures in crucibles were thermochemically treated in a preheated muffle furnace at different temperatures from $750{ }^{\circ} \mathrm{C}$ to $1150{ }^{\circ} \mathrm{C}$ for $30 \mathrm{~min}$. After thermochemical treatment, the crucibles were removed from the furnace and were allowed to cool at ambient conditions. During calcination and cooling, the crucibles were covered with a corundum lid to maintain reducing conditions. The samples were each pulverized in a vibrating cup mill made of tungsten carbide to prepare the samples for subsequent analysis.

\section{Pilot-scale trial}

The influence of the composition of the alkali additive $\left(\mathrm{Na}_{2} \mathrm{SO}_{4} / \mathrm{K}_{2} \mathrm{SO}_{4}\right)$ on the thermochemical process was investigated with a bench scale rotary kiln (RT1700, Thermal technology $\mathrm{GmbH}$ ). The kiln consists of a temperature resistant corundum ceramic tube that rotates in an oven heated by electric heating elements. The trial was operated at a cocurrent nitrogen gas flow of $300 \mathrm{~L} / \mathrm{h}$.

The feed material was a mixture of $3.0 \mathrm{~kg} \mathrm{SSA}, 0.75 \mathrm{~kg}$ SS and varying amounts and composition of alkali additive $\left(\mathrm{Na}_{2} \mathrm{SO}_{4}, \mathrm{~K}_{2} \mathrm{SO}_{4}\right)$. The materials were mixed in an Eirich (R02, Eirich) mixer for $5 \mathrm{~min}$ before processing in the rotary kiln. The composition of the alkali additives was (i) $1.39 \mathrm{~kg} \mathrm{Na}_{2} \mathrm{SO}_{4}$ (starting material mixture: L-Na), (ii) $0.66 \mathrm{~kg} \mathrm{Na}_{2} \mathrm{SO}_{4}$ and $0.77 \mathrm{~kg} \mathrm{~K}_{2} \mathrm{SO}_{4}$ (starting material mixture: L-K50) and (iii) $0.31 \mathrm{~kg} \mathrm{Na}_{2} \mathrm{SO}_{4}$ and $1.21 \mathrm{~kg} \mathrm{~K}_{2} \mathrm{SO}_{4}$ (starting material mixture: L-K75). The names of the trials with different composition of the alkali additive were chosen according to the molar ratio of $\mathrm{K}: \mathrm{Na}$ that was used. In opposite to the laboratory-scale experiment, the additive mixtures (K50, K75) were not preheated. The three mixtures were fed after each other into the rotary kiln without any break in the order L-Na, L-K50 and L-K75 (feeding rate $2.6 \mathrm{~kg} / \mathrm{h}$ ). Consequently, the ratio of $\mathrm{K}: \mathrm{Na}$ was increased along the rotary kiln trial.

The trial was done at a constant kiln set up temperature of $1000{ }^{\circ} \mathrm{C}$. The temperature in the tube was recorded by a manually held thermocouple of $3 \mathrm{~m}$ length (Type $\mathrm{K}$, electronic sensor, Heilbronn, Germany). The maximum temperature in the material bed was lower than the set kiln temperature and reached $950-970{ }^{\circ} \mathrm{C}$ in the center of the heating zone.

The trial lasted $9 \mathrm{~h}$. The first product could be sampled 45 min after start of feeding material. Subsequently, the product was collected in different charges. A new product sampling charge was started after every approx. $30 \mathrm{~min}$. Thus, we had finally eleven samples during $6 \mathrm{~h}$ sampling time. The twelfths product sample was collected after feeding stop and for a time period of $2 \mathrm{~h}$ and $10 \mathrm{~min}$. Each sample was milled in a cross-beater mill (SK300, Retsch GmbH, Haan, Germany). The milled samples were divided with a sample splitter to achieve a representative sub-sample of $100 \mathrm{~g}$. This was pulverized in a vibrating cup mill made of tungsten carbide and was used for subsequent analytics.

\section{Analysis}

\section{Total digestion}

Approximately $0.1 \mathrm{~g}$ of SSA or thermochemically treated ash was mixed with $4 \mathrm{~mL}$ of concentrated nitric acid $\left(\mathrm{HNO}_{3}\right)$, $1.5 \mathrm{~mL}$ perchloric acid $\left(\mathrm{HClO}_{4}\right)$, and $0.5 \mathrm{~mL}$ hydrofluoric acid $(\mathrm{HF})$ and was digested in a microwave (mikroPrepA, MLS GmbH, Leutkirch, Germany). Excess HF was complexed with $2.5 \mathrm{~mL}$ cold saturated boric acid $\left(\mathrm{HBO}_{3}\right)$. Additional information on the analysis and quality assurance can be found elsewhere [27, 28].

\section{Extraction in neutral ammonium citrate solution}

Extraction of $\mathrm{P}$ in neutral ammonium citrate solution was determined according to EU [29]. The amount of extractable $\mathrm{P}$ is defined as $\mathrm{P}_{\mathrm{NAC}}$. The ratio of soluble $\mathrm{P}$ and total amount of $\mathrm{P}$ is defined as $\mathrm{P}_{\mathrm{NAC} \text {,rel }}$. The elements $\mathrm{Ca}, \mathrm{K}, \mathrm{Mg}$ and $\mathrm{Na}$ were also measured in the extraction solution (Table 2).

\section{Determination of element content with ICP-OES}

The element concentrations of digestions solutions and extract in neutral ammonium citrate were measured by ICPOES (Thermo iCAP 7400, Dreieich, Germany). The total digestion and extraction solution were diluted by 1:100 and analyzed with a six-point-calibration, including the blank. Reference material CTA-FFA-1 [30] was used to evaluate precision of chemical analysis for $\mathrm{Al}, \mathrm{Ca}, \mathrm{Fe}, \mathrm{K}, \mathrm{Mg}$ and Na. Reference material U826-1 [31] was used for P and extractable $\mathrm{P}$ in citric acid [29]. The recovery was $89 \%$ for $\mathrm{Al}, 82 \%$ for $\mathrm{Ca}, 93 \%$ for $\mathrm{Fe}, 95 \%$ for $\mathrm{K}, 97 \%$ for $\mathrm{Mg}, 100 \%$ for $\mathrm{Na}, 93 \%$ for $\mathrm{P}, 98 \%$ for $\mathrm{Si}$ and $94 \%$ for extractable $\mathrm{P}$ in citric acid. 
Table 2 Extracted element mass fractions after extraction of selected thermochemical products with neutral ammonium citrate solution (NAC) displayed in wt.-\% with standard deviation (triplicates) and on the molar ratios normalized to $1 \mathrm{P}$ atom per formula unit. The calculated molar ratios are used for estimating P-phase composition

\begin{tabular}{|c|c|c|c|c|c|c|c|c|}
\hline \multirow[t]{3}{*}{ Series } & & \multicolumn{5}{|c|}{ Extracted chemical composition of P-phases } & \multirow{3}{*}{$\begin{array}{l}\text { Classification of crystal- } \\
\text { line P-phases according to } \\
\text { literature }\end{array}$} & \multirow{3}{*}{$\begin{array}{l}\text { Estimated P-phase composi- } \\
\text { tion after extraction in NAC }\end{array}$} \\
\hline & & \multicolumn{5}{|c|}{ After extraction in NAC } & & \\
\hline & & $\mathrm{Ca}$ & $\mathrm{Mg}$ & $\mathrm{Na}$ & $\mathrm{K}$ & $\mathrm{P}$ & & \\
\hline CT-Na & 1000 & $8.7 \pm 0.2$ & $0.5 \pm 0.05$ & $7.0 \pm 0.2$ & $0.01 \pm 0.0$ & $7.7 \pm 0.1$ & $\mathrm{CaNaPO}_{4}[37]+$ & \\
\hline molar ratio & & 0.87 & 0.09 & 1.23 & 0.00 & 1.00 & $\left(\mathrm{Ca}_{0.72} \mathrm{Mg}_{0.28}\right) \mathrm{NaPO}_{4}[22]$ & Two phases \\
\hline CT-K25 & 1000 & $8.1 \pm 0.3$ & $0.6 \pm 0.01$ & $5.6 \pm 0.1$ & $0.7 \pm 0.0$ & $7.2 \pm 0.1$ & $\mathrm{CaNaPO}_{4}[37]+$ & \\
\hline molar ratio & & 0.87 & 0.1 & 1.06 & 0.08 & 1.00 & $\left(\mathrm{Ca}_{0.72} \mathrm{Mg}_{0.28}\right) \mathrm{NaPO}_{4}[22]$ & Two phases \\
\hline CT-K50 & 1000 & $7.2 \pm 0.1$ & $1.0 \pm 0.01$ & $5.1 \pm 0.1$ & $1.6 \pm 0.2$ & $7.3 \pm 0.1$ & & \\
\hline molar ratio & & 0.77 & 0.18 & 0.94 & 0.18 & 1.00 & $\left(\mathrm{Ca}_{0.72} \mathrm{Mg}_{0.28}\right) \mathrm{NaPO}_{4}[22]$ & $\left(\mathrm{Ca}_{0.81} \mathrm{Mg}_{0.19}\right)\left(\mathrm{Na}_{0.84} \mathrm{~K}_{0.16}\right) \mathrm{PO}_{4}$ \\
\hline CT-K75 & 1050 & $7.1 \pm 0.2$ & $0.5 \pm 0.04$ & $2.9 \pm 0.1$ & $3.8 \pm 0.1$ & $6.4 \pm 0.1$ & & \\
\hline molar ratio & & 0.86 & 0.1 & 0.62 & 0.47 & 1.00 & $\mathrm{Ca}\left(\mathrm{Na}_{0.4} \mathrm{~K}_{0.6}\right) \mathrm{NaPO}_{4}[37]$ & $\left(\mathrm{Ca}_{0.90} \mathrm{Mg}_{0.10}\right)\left(\mathrm{Na}_{0.57} \mathrm{~K}_{0.43}\right) \mathrm{PO}_{4}$ \\
\hline CT-K100 & 1150 & $7.0 \pm 0.1$ & $0.7 \pm 0.01$ & $0.8 \pm 0.1$ & $6.3 \pm 0.2$ & $6.3 \pm 0.1$ & Unknown but similarities to & \\
\hline molar ratio & & 0.85 & 0.14 & 0.18 & 0.78 & 1.00 & $\mathrm{Ca}\left(\mathrm{Na}_{0.35} \mathrm{~K}_{0.65}\right) \mathrm{NaPO}_{4}$ [37] & $\left(\mathrm{Ca}_{0.86} \mathrm{Mg}_{0.14}\right)\left(\mathrm{Na}_{0.18} \mathrm{~K}_{0.82}\right) \mathrm{PO}_{4}$ \\
\hline
\end{tabular}

\section{Crystalline phase analysis by X-ray diffraction (XRD)}

Powder X-ray diffraction (XRD) analyses were done for fertilizer samples (Table 3) as well as for fertilizer samples after extraction in neutral ammonium citrate to verify reflexes disappearing due to extraction. Analyses were performed in Bragg-Brentano geometry over a $2 \theta$ range from $5^{\circ}$ to $80^{\circ}$, with a step size of $0.02^{\circ}$ (D8 Advance, Bruker AXS, Germany). The diffraction patterns were collected using $\mathrm{Cu}$ $\mathrm{K} \alpha 1 / \mathrm{K} \alpha 2(\lambda 1=1.54056 \AA / \lambda 2=1.54443 \AA)$ radiation. The diffraction patterns were recorded with a Lynxeye detector. Qualitative identification of the crystalline phases was performed using the MATCH! Software (version 3.6) [32] in combination with the PDF2 database [33].

\section{Different thermal analysis (DTA)}

Different thermal analysis (DTA) were carried out on a Netzsch STA 449 F3 Jupiter for mixtures of sodium and potassium sulfates (Fig. S2). The samples were heated with a rate of 10 Kelvin per minute from 30 to $1200{ }^{\circ} \mathrm{C}$ in an oxidizing atmosphere adjusted with synthetic air (80\% nitrogen and $20 \%$ oxygen).

Table 3 Semi-quantification of phase composition of one selected thermochemical product of each series at reaction temperature required for high $\mathrm{P}_{\mathrm{NAC}, \mathrm{rel}}$

\begin{tabular}{|c|c|c|c|c|c|c|c|c|c|}
\hline \multirow[t]{2}{*}{ Serie } & \multirow[t]{2}{*}{$\mathrm{T}\left[{ }^{\circ} \mathrm{C}\right]$} & \multicolumn{3}{|c|}{ Phosphate phases } & \multicolumn{5}{|c|}{ Other phases } \\
\hline & & $\mathrm{CaNaPO}_{4}$ & $(\mathrm{Ca}, \mathrm{Mg}) \mathrm{NaPO}_{4}$ & $\mathrm{Ca}(\mathrm{Na}, \mathrm{K}) \mathrm{PO}_{4}$ & Lazurite* & $\begin{array}{l}(\mathrm{Na}, \mathrm{K}) \\
\mathrm{AlSiO}_{4} \\
\text { Nepheline }\end{array}$ & $\mathrm{KAlSiO}_{4} * *$ & $\begin{array}{l}\mathrm{KAlSi}_{2} \mathrm{O}_{6} \\
\text { Leucite }\end{array}$ & $\mathrm{Fe}_{3} \mathrm{O}_{4}$ Magnetite \\
\hline CT-Na & 1000 & & & - & & & - & - & \\
\hline CT-K25 & 1000 & 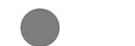 & & - & - & & - & & \\
\hline CT-K50 & 1000 & - & & - & - & - & & & \\
\hline CT-K75 & 1050 & - & - & 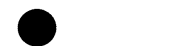 & - & - & & & \\
\hline CT-K100 & 1150 & - & - & 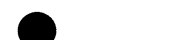 & - & - & & & \\
\hline
\end{tabular}

Meaning of symbols: '-' not detected, $\bigcirc$ low $\bigcirc$ medium $\bigcirc$ high amount. This quantification is a rude semi-quantification with comparison of reflex intensity and chemical composition. Assumed chemical composition for $(\mathrm{Ca}, \mathrm{Mg}) \mathrm{NaPO}_{4}$ and $\mathrm{Ca}(\mathrm{Na}, \mathrm{K}) \mathrm{PO}_{4}$ are listed in Table 2. $* \mathrm{Na}_{3} \mathrm{CaSi}_{3} \mathrm{Al}_{3} \mathrm{O}_{12} \mathrm{~S} * *$ Two modifications of $\mathrm{KAlSiO}_{4}$ 


\section{Results}

\section{Thermochemical treatment in laboratory scale crucible experiments}

\section{Characterization of additives}

Three mixtures of $\mathrm{Na}_{2} \mathrm{SO}_{4}$ and $\mathrm{K}_{2} \mathrm{SO}_{4}$ (not pre-heated) in the molar ratios 75:25 for CT-K25; 50:50 for CT-K50 and 25:75 for CT-K75 were analyzed with DTA. During heating, the characteristic phase transition points of $\mathrm{Na}_{2} \mathrm{SO}_{4}$ at approx. $253{ }^{\circ} \mathrm{C}$ and of $\mathrm{K}_{2} \mathrm{SO}_{4}$ at $584{ }^{\circ} \mathrm{C}$ are visible (Fig. S2). The temperatures of melting points are comparable to the temperatures of desired composition of mixtures of $\mathrm{Na}_{2} \mathrm{SO}_{4}$ and $\mathrm{K}_{2} \mathrm{SO}_{4}$ according to Rowe [26] (Fig. S2, Table 4).

These three mixtures were afterwards pre-heated at $600{ }^{\circ} \mathrm{C}$ and analyzed by XRD analysis after cooling. They contain different amounts of crystalline phases $\mathrm{K}_{3} \mathrm{Na}\left(\mathrm{SO}_{4}\right)_{2}$, $\mathrm{Na}_{2} \mathrm{SO}_{4}, \mathrm{NaKSO}_{4}$ and $\mathrm{K}_{2} \mathrm{SO}_{4}$ related to the $\mathrm{Na}$ and $\mathrm{K}$ portion in mixtures of $\mathrm{Na}_{2} \mathrm{SO}_{4}$ and $\mathrm{K}_{2} \mathrm{SO}_{4}$ (Fig. S3).

\section{Correlation between temperature and extractable phosphorus $\left(\mathrm{P}_{\mathrm{NAC}, \mathrm{rel}}\right)$}

Sewage sludge ash was thermochemically treated with $\mathrm{Na}_{2} \mathrm{SO}_{4}, \mathrm{~K}_{2} \mathrm{SO}_{4}$ and their mixtures (series CT-Na to CT-K100) in corundum crucibles at different temperatures. The aim was to identify the required temperature to achieve a high extractable $\mathrm{P}$ in neutral ammonium citrate, indicated as $\mathrm{P}_{\mathrm{NAC} \text {,rel }}$. in Fig. 1. The data show a clear correlation of $\mathrm{P}_{\mathrm{NAC}, \mathrm{rel}}$ and treatment temperature for all tested additives and are described with regression curves of a dose-response four-parameter logistic function [34]. The lowest measured $\mathrm{P}_{\mathrm{NAC} \text {,rel }}$ in each series were between $40-50 \%$. The $\mathrm{P}_{\mathrm{NAC} \text {,rel }}$ increased at different temperatures in these experiments. The point of increase of $\mathrm{P}_{\mathrm{NAC} \text {,rel }}$ correlated with melting points in the phase diagram $\mathrm{Na}_{2} \mathrm{SO}_{4}-\mathrm{K}_{2} \mathrm{SO}_{4}$ [26].

Sewage sludge ash treated with $\mathrm{Na}_{2} \mathrm{SO}_{4}$ has the strongest extractability increase in the temperature range $800-900{ }^{\circ} \mathrm{C}$ around the melting point $894{ }^{\circ} \mathrm{C}$ of $\mathrm{Na}_{2} \mathrm{SO}_{4}$. The maximum

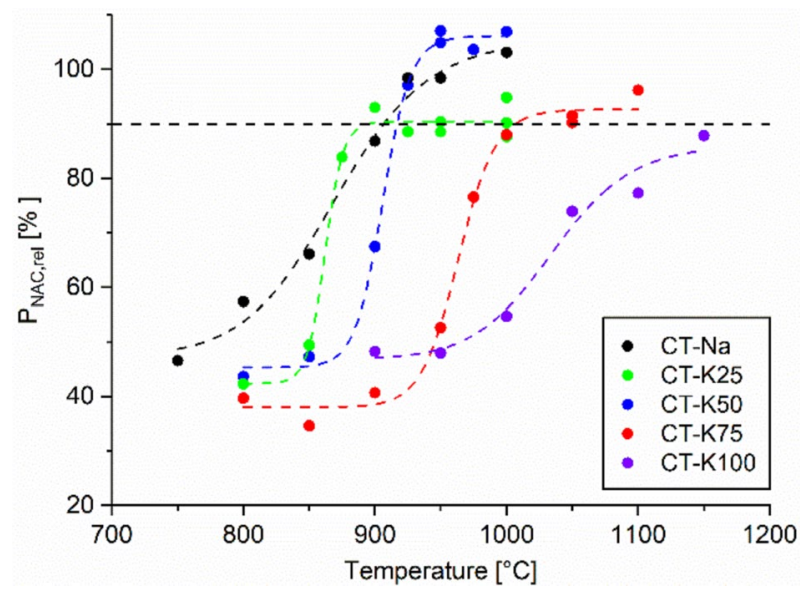

Fig. $1 \mathrm{P}_{\mathrm{NAC}, \text { rel }}$ of products thermochemically treated in crucibles at different temperatures of five series with different additive mixtures of $\mathrm{Na}_{2} \mathrm{SO}_{4}$ and $\mathrm{K}_{2} \mathrm{SO}_{4}$ (number in series name represent molar portion of $\mathrm{K}_{2} \mathrm{SO}_{4}$ in additive). Total ratio of $(\mathrm{Na}+\mathrm{K}) / \mathrm{P}$ was $2 \mathrm{~mol} / \mathrm{mol}$ in starting material. The horizontal dashed line represents $90 \% \mathrm{P}_{\mathrm{NAC} \text {,rel }}$. Colored dashed curves are regression curves of a dose-response fourparameter logistic function [34] (color figure online)

level of $90-100 \%$ were above $925^{\circ} \mathrm{C}$ and is confirmed by experiments by Herzel et al. [10] and Herzel et al. [15].

$\mathrm{P}_{\mathrm{NAC}, \mathrm{rel}}$ for a treatment with $\mathrm{K}_{2} \mathrm{SO}_{4}$ by Herzel et al. [10] correlates also with current results. In this previous study, approximately half of $\mathrm{P}$ was soluble in neutral ammonium citrate for a K/P-molar ratio of 2.0. We observed a $\mathrm{P}_{\mathrm{NAC} \text {,rel }}$ of $55 \%$ at $1000{ }^{\circ} \mathrm{C}$. The maximum $\mathrm{P}_{\mathrm{NAC} \text {,rel }}$ was observed at the maximum temperature in the experiment of $1150{ }^{\circ} \mathrm{C}$ with approximately $90 \%$ and correlates with the melting point of $\mathrm{K}_{2} \mathrm{SO}_{4}$ of $1070{ }^{\circ} \mathrm{C}$. Higher temperatures were not investigated as SSA started to melt at these temperatures. The melt would react with the corundum crucible changing the chemical system. A thermochemical treatment with $\mathrm{K}_{2} \mathrm{SO}_{4}$ is not suitable for a technical process due to the high temperature required for the reaction of the phosphate phases in $\mathrm{SSA}$ with $\mathrm{K}_{2} \mathrm{SO}_{4}$.

Nevertheless, a K-containing additive is desirable to increase the $\mathrm{K}$ content of the recycling fertilizer. Therefore, reaction temperatures were investigated when $\mathrm{K}_{2} \mathrm{SO}_{4}$ is
Table 4 Sufficient reaction temperature to achieve $P_{\text {NAC,rel }} \geq 90 \%$ for thermochemical treatment compared with melting points of alkali additives: ${ }^{1)}$ measured temperature of melting point of used $\mathrm{Na}_{2} \mathrm{SO}_{4} / \mathrm{K}_{2} \mathrm{SO}_{4}$ with differential thermal analysis (DTA) (Fig. S2) and ${ }^{2)}$ melting point according to Rowe [26]

\begin{tabular}{|c|c|c|c|c|}
\hline \multirow[t]{2}{*}{ Series } & \multirow{2}{*}{$\begin{array}{l}\mathrm{K}_{2} \mathrm{SO}_{4} \text { in addi- } \\
\text { tive [mol\%] }\end{array}$} & \multirow{2}{*}{$\begin{array}{l}\text { Treated ash } \\
\text { Sufficient reaction tempera- } \\
\text { tures for } \mathrm{P}_{\mathrm{NAC}, \text { rel }} \geq 90 \%\left[{ }^{\circ} \mathrm{C}\right]\end{array}$} & \multicolumn{2}{|c|}{ Alkali sulfate additives } \\
\hline & & & $\begin{array}{l}\text { Measured melting } \\
\text { points of additives }{ }^{1)} \\
{\left[{ }^{\circ} \mathrm{C}\right]}\end{array}$ & $\begin{array}{l}\text { Temperature of } \\
\text { melting point }{ }^{2)} \\
{\left[{ }^{\circ} \mathrm{C}\right]}\end{array}$ \\
\hline CT-Na & 0 & 925 & 888 & 894 \\
\hline CT- K25 & 25 & 900 & 838 & 823 \\
\hline CT- K50 & 50 & 925 & 865 & 910 \\
\hline CT- K75 & 75 & 1000 & 948 & 1000 \\
\hline CT-K100 & 100 & 1150 & 1073 & 1071 \\
\hline
\end{tabular}


partly substituted by $\mathrm{Na}_{2} \mathrm{SO}_{4}$ in an additive mixture. $\mathrm{K}_{2} \mathrm{SO}_{4}$ was substituted by $25 \mathrm{~mol} \%$ (CT-K75), $50 \mathrm{~mol} \%$ (CT-K50) and $75 \mathrm{~mol} \%$ (CT-K25) $\mathrm{Na}_{2} \mathrm{SO}_{4}$.

One quarter substitution results in a significant temperature reduction to achieve high $\mathrm{P}_{\mathrm{NAC}, \text { rel }}$. It increased from 50 to $90 \%$ in the temperature range from $950{ }^{\circ} \mathrm{C}$ to $1000{ }^{\circ} \mathrm{C}$ and is constant at higher temperatures. In case of substitution of $50 \mathrm{~mol} \%$ (CT-K50), P was nearly completely extractable in neutral ammonium citrate after treatment at $925{ }^{\circ} \mathrm{C}$. Series CT-K25 (substitution $75 \mathrm{~mol} \%$ ) has the lowest reaction temperature of all five series. More than $90 \%$ of $\mathrm{P}$ was extractable in neutral ammonium citrate after thermochemical treatment at $900{ }^{\circ} \mathrm{C}$ (Fig. 1).

\section{Phase analysis in laboratory-scale calcination experiments}

The phase analysis of thermochemical products was done with samples in which the highest $\mathrm{P}_{\mathrm{NAC} \text {,rel }}$ levels were achieved $\left(1000{ }^{\circ} \mathrm{C}\right.$ for all samples, except $1050{ }^{\circ} \mathrm{C}$ for CT-K75 and $1150{ }^{\circ} \mathrm{C}$ for CT-K100). The sample names include the reaction temperature (e.g., CT-Na-1000). The added $\mathrm{Na}_{2} \mathrm{SO}_{4}$ and $\mathrm{K}_{2} \mathrm{SO}_{4}$ react with phosphate phases as well as with quartz in the SSA. Furthermore, the amount of amorphous phase is decreased after thermochemical treatment. This means more crystalline phases are available in the thermochemical products because additives react with e.g., $\mathrm{Al}_{2} \mathrm{O}_{3}$ and $\mathrm{SiO}_{2}$ from the amorphous phase [35] and form crystalline phases.

The different content of $\mathrm{Na}$ and $\mathrm{K}$ in series CT-Na-1000 to CT-K100-1150 changed the $\mathrm{Na}$ and $\mathrm{K}$ contents in the silicates formed (Table 3). Na-containing nepheline $((\mathrm{Na}, \mathrm{K})$ $\mathrm{AlSiO}_{4}$ ) was identified in samples CT-Na-1000 and CT-K251000 and was replaced by $\mathrm{KAlSiO}_{4}$-phases in the other samples (CT-K50-1000, CT-K75-1050 and CT-K100-1150). Furthermore, the fraction of leucite $\left(\mathrm{KAlSi}_{2} \mathrm{O}_{6}\right)$ decreases with increasing $\mathrm{K}$ content and is replaced by $\mathrm{KAlSiO}_{4}$. Only, CT-Na-1000 contains a sulfur bearing silicate phase which belongs to the sodalite group. The assumed composition of $\mathrm{Na}_{3} \mathrm{CaAl}_{3} \mathrm{Si}_{3} \mathrm{O}_{12} \mathrm{~S}$ belongs to the lazurite group but many isostructural types exist. Sulfur containing silicates were previously observed by Stemann et al. [14] using $\mathrm{Na}_{2} \mathrm{SO}_{4}$ as additive.

The $\mathrm{P}$ phases whitlockite and $\mathrm{AlPO}_{4}$ in SSA (Fig. S1) are transformed due to thermochemical treatment to calcium alkali phosphates $\left(\mathrm{Ca}(\mathrm{Na}, \mathrm{K}) \mathrm{PO}_{4}\right)$. Furthermore, Calcium $(\mathrm{Ca})$ could be partly substituted by Magnesium $(\mathrm{Mg})$. Sodium-rich samples (CT-Na-1000, CT-K25-1000 and CT-K50-1000) contain the low temperature modification of $\mathrm{CaNaPO}_{4}$ (ICDD PDF entry 00-029-1193) and (Ca,Mg) $\mathrm{NaPO}_{4}$ (Table 3). The latter correlates to the reflexes of the data base entry for $\left(\mathrm{Ca}_{0.72} \mathrm{Mg}_{0.28}\right) \mathrm{NaPO}_{4}$ (ICDD PDF entry 01-088-1548). A reflex shift in the diffraction pattern indicated that this phase contained less $\mathrm{Mg}$ compared to $\mathrm{Ca}$
(Fig. 2). Thus, the composition is most likely $\left(\mathrm{Ca}_{0.8} \mathrm{Mg}_{0.2}\right)$ $\mathrm{NaPO}_{4}$. CT-Na-1000 and CT-K25-1000 mainly contain $\mathrm{CaNaPO}_{4}$ and less $(\mathrm{Ca}, \mathrm{Mg}) \mathrm{NaPO}_{4}$. Only $(\mathrm{Ca}, \mathrm{Mg}) \mathrm{NaPO}_{4}$ was detected in CT-K50-1000 (Fig. 2 and Table 3) and is confirmed by increased content of $\mathrm{Mg}$ in solution after extraction in neutral ammonium citrate (Table 2). The chemical composition of $\mathrm{P}$ phase in CT-K50-1000 is assumed as $\left(\mathrm{Ca}_{0.81} \mathrm{Mg}_{0.19}\right)\left(\mathrm{Na}_{0.84} \mathrm{~K}_{0.16}\right) \mathrm{PO}_{4}$ (Table 2).

The identifications of crystalline P-phases in samples CT-K75-1050 and CT-K100-1150 were difficult because no data base entry for $P$ phases correlates very well. To identify the P-bearing crystalline phases, the ash was analyzed by XRD before and after extraction with neutral ammonium citrate (Fig. 3). The reflexes which are disappeared after extraction are located between reflexes of high-temperature modification of $\mathrm{CaNaPO}_{4}$ and $\mathrm{CaKPO}_{4}[36]$ (Table 3). Additionally, reflex positions were compared with pure $\mathrm{Ca}(\mathrm{Na}, \mathrm{K})$ $\mathrm{PO}_{4}$-phases with different portion of $\mathrm{K}$ and $\mathrm{Na}$ (Fig. 3). The reflexes in CT-K75-1050 are comparable to synthesized phase $\mathrm{Ca}\left(\mathrm{Na}_{0.4} \mathrm{~K}_{0.6}\right) \mathrm{PO}_{4}$ [37] but shifted to higher angles indicating a lower $\mathrm{K}$ content (Fig. 3). This is confirmed by an estimated phase composition of $\left(\mathrm{Ca}_{0.90} \mathrm{Mg}_{0.10}\right)$ $\left(\mathrm{Na}_{0.57} \mathrm{~K}_{0.43}\right) \mathrm{PO}_{4}$ (Table 2). The reflexes in CT-K100-1150 are located between samples $\mathrm{Ca}\left(\mathrm{Na}_{0.35} \mathrm{~K}_{0.65}\right) \mathrm{PO}_{4}$ and high temperature modification of $\mathrm{CaKPO}_{4}$ [37] and correspond to the estimated phase composition $\left(\mathrm{Ca}_{0.86} \mathrm{Mg}_{0.14}\right)\left(\mathrm{Na}_{0.18} \mathrm{~K}_{0.82}\right)$

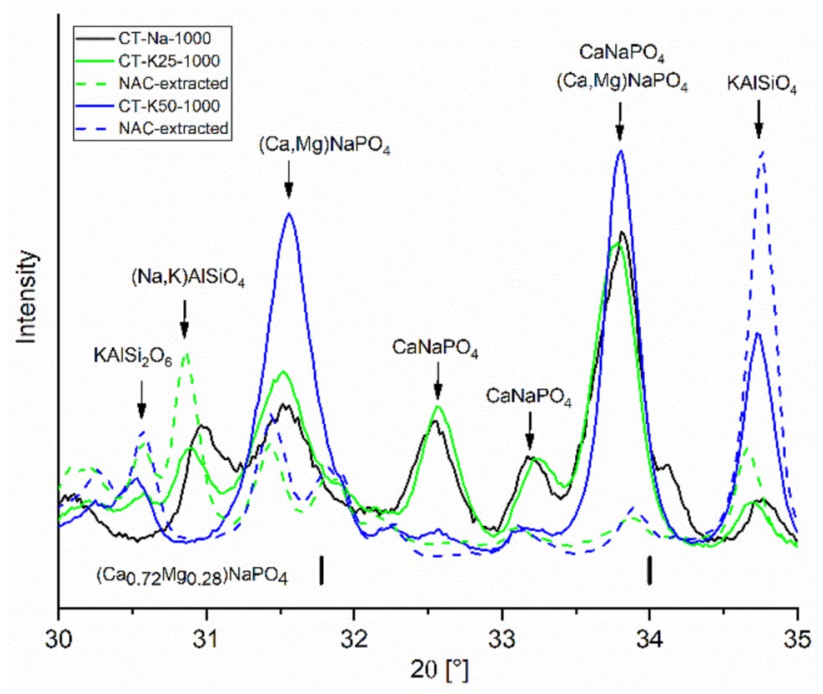

Fig. 2 Sections of diffractograms of samples CT-Na-1000 (black), CT-K25-1000 (green) and CT-K50-1000 (blue). The dashed diffractograms represents diffractograms of CT-K25-1000 (dashed green) and CT-K50-1000 (dashed blue) after extraction in neutral ammonium citrate solution (NAC-extracted). Reflexes of phosphate phases $\mathrm{CaNaPO}_{4}$ and $(\mathrm{Ca}, \mathrm{Mg}) \mathrm{NaPO}_{4}$ vanish and reflexes of silicate phases $\left(\mathrm{KAlSi}_{2} \mathrm{O}_{6},(\mathrm{Na}, \mathrm{K}) \mathrm{AlSiO}_{4}, \mathrm{KAlSiO}_{4}\right.$,) are pronounced after NACextraction. Reflexes of $(\mathrm{Ca}, \mathrm{Mg}) \mathrm{NaPO}_{4}\left(31.5^{\circ}, 33.8^{\circ}\right)$ are shifted to smaller angles compared to ICDD PDF data base entry 01-088-1548 for $\left(\mathrm{Ca}_{0.72} \mathrm{Mg}_{0.28}\right) \mathrm{NaPO}_{4}\left(31.8^{\circ}, 34.0^{\circ}\right)$ (color figure online) 


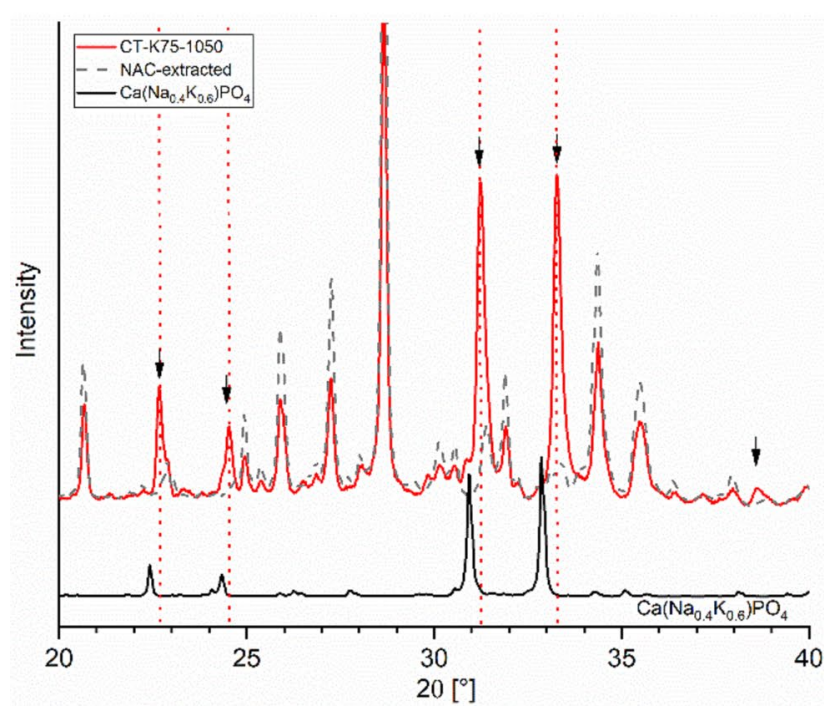

Fig. 3 Sections of diffractograms of samples CT-K75-1050 (left) and CT-K100-1150 (right). The dashed diffractograms after NACextraction. Arrows mark and dotted vertical lines marked reflexes vanished after NAC-extraction. Diffractogram of synthesized sample

$\mathrm{PO}_{4}$. Thus, phase modification of $\mathrm{CaKPO}_{4}$ incorporated $\mathrm{Na}$ and has different reflexes (Fig. 3) as previous reported phase modification of $\mathrm{CaKPO}_{4}[24,37]$.

\section{Pilot trials in a rotary kiln}

\section{Pilot-scale observations}

The pilot-scale trial (L) in the rotary kiln was conducted at kiln set up temperature of $1000{ }^{\circ} \mathrm{C}$. The measured temperature in the material bed in the tube was $950-970{ }^{\circ} \mathrm{C}$. Adhesion of the material was observed at the hot walls of the tube. Thus, a material ring continuously formed had to be removed every $20 \mathrm{~min}$. The clogging effect was even more pronounced compared to Herzel et al. [15] because the kiln has a smaller diameter and its corundum tube has a porous ceramic surface. The material adhesions were unchanged over the whole trial including variation of starting materials (L-Na, L-K50, L-K75).

A mass flow at the outlet of about $2.1 \mathrm{~kg} / \mathrm{h}$ was expected (material feeding rate of $2.6 \mathrm{~kg} / \mathrm{h}$, total mass yield of $80 \%$ mainly due to combustion of organic compounds in SS). The measured mass flows were approx. $1.5 \mathrm{~kg} / \mathrm{h}$. Thus, a certain storage of material in the kiln was observed.

\section{Extractable phosphorus and change of alkali content}

The ratios of alkali additives $\mathrm{Na}_{2} \mathrm{SO}_{4}$ and $\mathrm{K}_{2} \mathrm{SO}_{4}$ were varied to evaluate how the portion of $\mathrm{K}_{2} \mathrm{SO}_{4}$ in the additive influences $\mathrm{P}_{\mathrm{NAC} \text {,rel }}$. Laboratory-scale experiments show

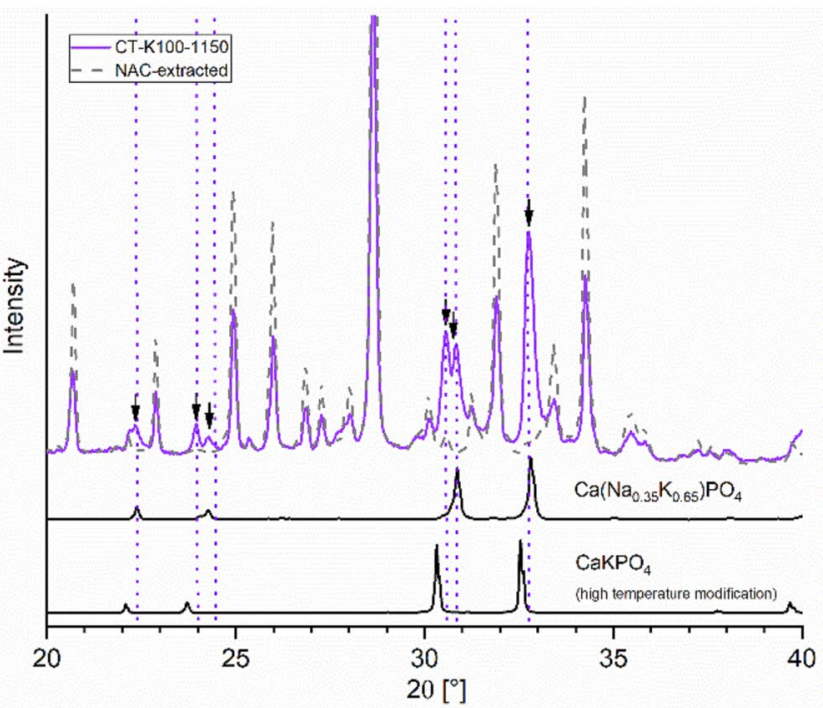

$\mathrm{Ca}\left(\mathrm{Na}_{0.4} \mathrm{~K}_{0.6}\right) \mathrm{PO}_{4}, \mathrm{Ca}\left(\mathrm{Na}_{0.35} \mathrm{~K}_{0.65}\right) \mathrm{PO}_{4}, \mathrm{CaKPO}_{4}$ (high temperature modification) [37] are displayed for comparison of reflex positions (color figure online)

that the mixture of $\mathrm{Na}_{2} \mathrm{SO}_{4}$ and $\mathrm{K}_{2} \mathrm{SO}_{4}$ needs minimal $25 \mathrm{~mol} \% \mathrm{Na}_{2} \mathrm{SO}_{4}$ (series CT-K75) to achieve a high $\mathrm{P}_{\mathrm{NAC} \text {,rel }}$ at $1000^{\circ} \mathrm{C}$ (Fig. 1). Based on this data, the same amounts of SSA, SS and alkali additives were used to conduct a rotary kiln trial using the starting materials mixtures (L-K50 and L-K75).

The first material charging was starting materials mixtures with additive $\mathrm{Na}_{2} \mathrm{SO}_{4}$ (L-Na, in total $5.14 \mathrm{~kg}$ ). After $45 \mathrm{~min}$, the first material product was collected for half an hour. The treatment increased the $\mathrm{P}_{\mathrm{NAC}, \text { rel }}$ from $35 \%$ in SSA to $73 \%$ in the thermochemical product. The content of $\mathrm{Na}$ in the product was $11 \mathrm{wt} .-\%$ in agreement with the adjusted additive dosing (Fig. 4).

The second materials charging (L-K50, in total $5.18 \mathrm{~kg}$ ) was immediately after feeding with first charging was finished after $1.5 \mathrm{~h}$. Consequently, the $\mathrm{K}$ content increased continuously and was constant at $6 \mathrm{wt} . \%$ in sample L-5, L-6 and L-7, in parallel the Na content decreased to 7-8 wt.-\%. $\mathrm{P}_{\mathrm{NAC}, \text { rel }}$ varied between 65 to $73 \%$ for samples L-3 till L-7 (Fig. 4).

Feeding of the third starting material L-K75 (in total $5.27 \mathrm{~kg}$ ) after $4 \mathrm{~h}$ increased the $\mathrm{K}$ content up to $10 \mathrm{wt} .-\%$ and $\mathrm{P}_{\mathrm{NAC} \text {,rel }}$ decreased at the same time to $50 \%$. The last sample 12 represents the product material after feeding stop resulting in decreasing material bed and is therefore not representative for any defined process condition (Fig. 4).

This rotary kiln trial shows very well how the $\mathrm{Na}$ and $\mathrm{K}$ contents adjusted by the additive mixtures influence the fraction of $\mathrm{P}$ extractable in neutral ammonium citrate and thus its availability to plants. The $\mathrm{P}_{\mathrm{NAC}, \text { rel }}$ varied between 65 


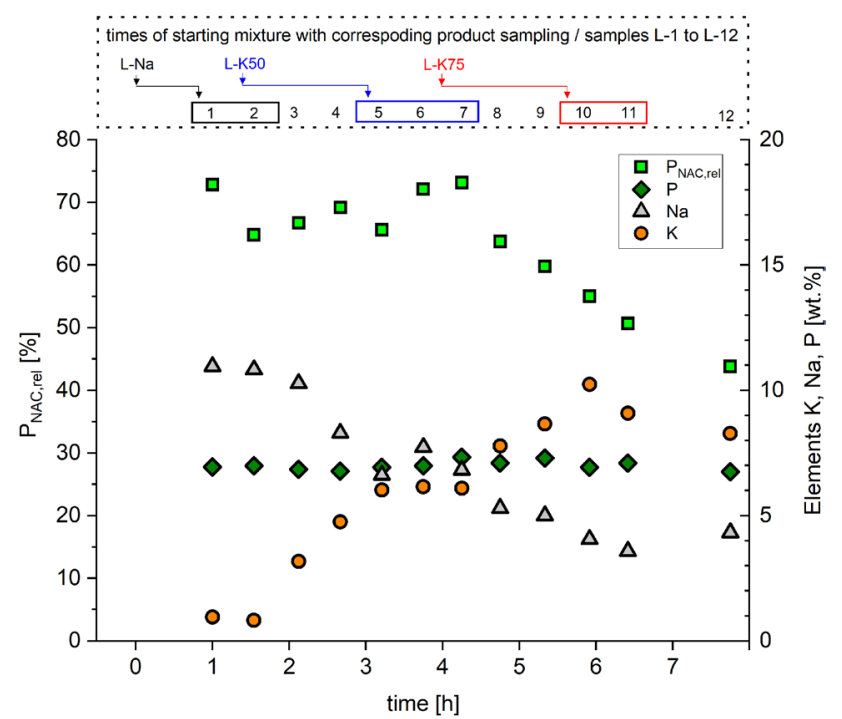

Fig. 4 Chemical composition of product samples in the pilot-trial at 950-970 ${ }^{\circ} \mathrm{C}$ (measured in material bed). Displayed $\mathrm{P}_{\mathrm{NAC}, \text { rel }}$ (in \%), $\mathrm{K}$, $\mathrm{Na}$ and $\mathrm{P}$ (in wt.\%) are values for a collected sample (30-40 min collecting time) of twelve samples (L-1 to L-12). Above graph is time point of feeding new starting material mixtures (L-Na, L-K50 and L-K75) and corresponding product sample number (L-Na: L-1 to L-2; L-K50: L-5 to L-7; L-K75: L-10 to L-11). The chosen colors (black, blue, red) are the same as in Fig. 1 for comparable starting materials (color figure online)

and 75\% during the L-Na and L-K50 campaigns and continuously decreased during the L-K75 campaign to values below $50 \%$ (Fig. 4).

\section{Phase analysis in pilot trial}

$\mathrm{P}_{\mathrm{NAC}, \text { rel }}$ in the products of pilot-scale trial (Fig. 4) were significantly lower compared to the products of the corresponding laboratory-scale crucible experiments (Fig. 1). This suggests that the transformation from less soluble whitlockite and $\mathrm{AlPO}_{4}$ in the SSA (Fig. S1) [11, 38] to highly NACextractable calcium alkali phosphates was not complete. This is confirmed by X-ray diffraction analysis done with the eleven samples from the pilot trial (sample names L-1 to L-11) (Table S1).

The identified highly NAC-extractable phases are mainly (Ca, $\mathrm{Mg}) \mathrm{NaPO}_{4}$ and minor $\mathrm{CaNaPO}_{4}$. In the pilot trial, portions of these highly NAC-extractable phases decreased to the expense of whitlockite (Table $\mathrm{S} 1$ ) resulting in a drop of $\mathrm{P}_{\mathrm{NAC}, \text { rel }}$ after $4.5 \mathrm{~h}$ (L-8) (Fig. 4). There was no detectable K-containing calcium alkali phosphate, while the $\mathrm{K}$ content in the products increased (Fig. 4).

Sodium-rich silicates phases changed to K-rich phases due to increased $\mathrm{K}$ addition over time. Lazurite $\left[\mathrm{Na}_{3} \mathrm{CaAl}_{3} \mathrm{Si}_{3} \mathrm{O}_{12} \mathrm{~S}\right]$ and sodium nepheline $\left[\mathrm{NaAlSiO}_{4}\right]$ is substituted by $(\mathrm{Na}, \mathrm{K}) \mathrm{AlSiO}_{4}$ and $\mathrm{Kalsilite}\left[\mathrm{KAlSiO}_{4}\right]$ and

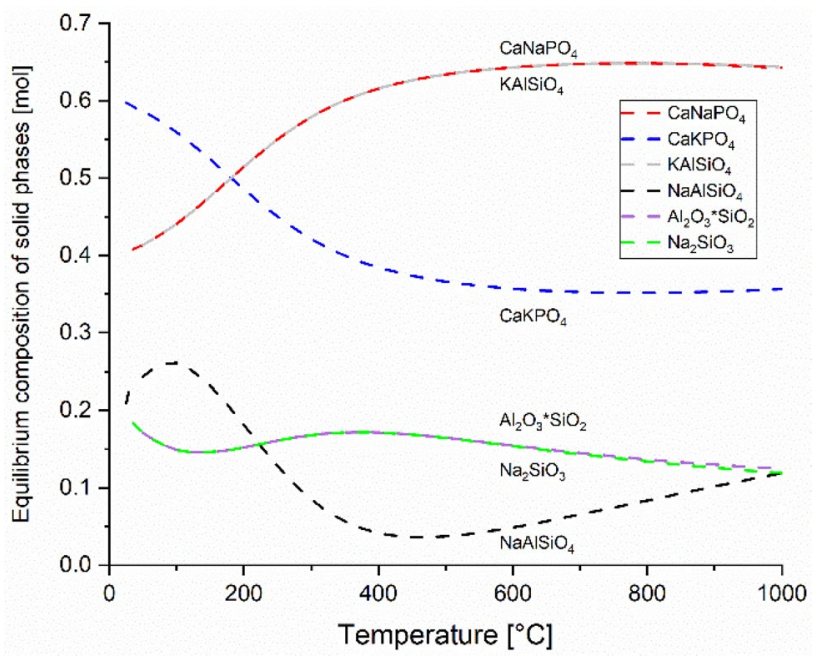

Fig. 5 Equilibrium compositions of the solid phase products depending on temperature using the thermodynamic calculation software HSC Chemistry. The input element species were adjusted analogous to trial series CT-K50 $\left(0.25 \mathrm{Al}_{2} \mathrm{O}_{3}, 0.5 \mathrm{AlPO}_{4}, 0.25 \mathrm{CaO}, 0.25\right.$ $\mathrm{Ca}_{3}\left(\mathrm{PO}_{4}\right)_{2}, 0.5 \mathrm{~K}_{2} \mathrm{O}, 0.5 \mathrm{Na}_{2} \mathrm{O}$ and $\left.1.0 \mathrm{SiO}_{2}\right)$

Leucite $\left[\mathrm{KAlSi}_{2} \mathrm{O}_{6}\right]$ (Table $\mathrm{S} 1$ ). The incomplete reaction between phosphates and alkali sulfates leads to remain not reacted alkali sulfates in form of $\mathrm{Na}_{2} \mathrm{SO}_{4}, \mathrm{~K}_{3} \mathrm{Na}\left(\mathrm{SO}_{4}\right)_{2}$ and $\mathrm{K}_{2} \mathrm{SO}_{4}$ and resulting also in a $\mathrm{SiO}_{2}$ increase (Table $\mathrm{S} 1$ ).

\section{Thermodynamic considerations}

Thermodynamic calculations were carried out with the software HSC Chemistry 6.1 (Outotec, Oberursel, Germany) [39] with similar condition as in the crucible trials series CT-K25, CT-K50 and CT-K75. The thermodynamic calculations were done in the temperature range $25-1000{ }^{\circ} \mathrm{C}$. The starting element species were given in mol as $0.25 \mathrm{Al}_{2} \mathrm{O}_{3}$, $0.5 \mathrm{AlPO}_{4}, 0.25 \mathrm{CaO}, 0.25 \mathrm{Ca}_{3}\left(\mathrm{PO}_{4}\right)_{2}, 0.5 \mathrm{~K}_{2} \mathrm{O}, 0.5 \mathrm{Na}_{2} \mathrm{O}$ and $1.0 \mathrm{SiO}_{2}$ for HSC-K50 (Fig. 5). Thus, $1 \mathrm{~mol}$ of each element ( $\mathrm{Al}, \mathrm{Ca}, \mathrm{K}, \mathrm{Na}, \mathrm{P}, \mathrm{Si}$ ) is present in the calculation. Further calculations contain $0.75 \mathrm{~mol} \mathrm{Na}_{2} \mathrm{O} / 0.25 \mathrm{~mol} \mathrm{~K}_{2} \mathrm{O}$ related to CT-K25 and $0.25 \mathrm{~mol} \mathrm{Na}_{2} \mathrm{O} / 0.75 \mathrm{~mol} \mathrm{~K}_{2} \mathrm{O}$ related to CT-K75 in Fig. S4.

This element species system was simplified by excluding magnesium and iron. The calculation was done in an oxidizing atmosphere $\left(80 \% \mathrm{~N}_{2}, 20 \% \mathrm{O}_{2}\right) \cdot \mathrm{Na}_{2} \mathrm{O}$ and $\mathrm{K}_{2} \mathrm{O}$ were used instead of $\mathrm{Na}_{2} \mathrm{SO}_{4}$ and $\mathrm{K}_{2} \mathrm{SO}_{4}$ because sulfates react as separate phases in this thermodynamic calculation. The data base of software HSC chemistry does not contain any $\mathrm{Ca}(\mathrm{Na}, \mathrm{K})$ $\mathrm{PO}_{4}$ species. Therefore, standard enthalpy of formation, standard entropy and coefficients for heat capacity for endmembers $\mathrm{CaNaPO}_{4}$ and $\mathrm{CaKPO}_{4}$ were taken from Herzel et al. [37]. Thermodynamic data for intermediate $\mathrm{Ca}(\mathrm{Na}, \mathrm{K})$ $\mathrm{PO}_{4}$ were not considered because these data are incomplete. The calculations include all element species for which data 
for heat capacity up to $950{ }^{\circ} \mathrm{C}$ are available. An exception is $\mathrm{KAlSiO}_{4}$ (Kalsilite) as heat capacity data are only available up to $537^{\circ} \mathrm{C}$ in HSC Chemistry. Therefore, these data were substituted by similar data for Kalsilite $\left(25-537^{\circ} \mathrm{C}\right)$ and by data for high kaliophillite $\left(537-1527^{\circ} \mathrm{C}\right)$ from Robie and Hemingway [40].

These calculations resulted in six main element species $\mathrm{Al}_{2} \mathrm{O}_{3}{ }^{*} \mathrm{SiO}_{2}, \mathrm{CaNaPO}_{4}, \mathrm{CaKPO}_{4}, \mathrm{KAlSiO}_{4}, \mathrm{NaAlSiO}_{4}$ and $\mathrm{Na}_{2} \mathrm{SiO}_{3}$. Further element species were below $0.03 \mathrm{kmol}$ und were thus negligible. Amounts of the same chemical element species for $\mathrm{KAlSiO}_{4}$ (kaliophilite, kalsilite/high kaliophilite) and $\mathrm{NaAlSiO}_{4}$ (kalsilite, nepheline) were summed up in Fig. 5 and S4.

The calculation shows that the formation of the element species does not further change above $500{ }^{\circ} \mathrm{C}$ (Fig. 5). The amounts of $\mathrm{CaNaPO}_{4}$ and $\mathrm{KAlSiO}_{4}$ are at the same level of around $0.65 \mathrm{kmol}$. The amount of $\mathrm{CaKPO}_{4}(0.35 \mathrm{kmol})$ is in the same level as the sum of the silicate species $\mathrm{NaAlSiO}_{4}$, $\mathrm{Na}_{2} \mathrm{SiO}_{3}$ and $\mathrm{Al}_{2} \mathrm{O}_{3} * \mathrm{SiO}_{2}$. Thus, the element species distribution can be divided in two groups. The dominant group contains $\mathrm{CaNaPO}_{4}+\mathrm{KAlSiO}_{4}$ and the subordinated group $\mathrm{CaKPO}_{4}, \mathrm{NaAlSO}_{4}, \mathrm{Na}_{2} \mathrm{SiO}_{3}$ and $\mathrm{Al}_{2} \mathrm{O}_{3} * \mathrm{SiO}_{2}$ in case $\mathrm{Na}_{2} \mathrm{O}$ and $\mathrm{K}_{2} \mathrm{O}$ were added in equal amounts of $0.5 \mathrm{~mol}$ (HSCK50). Further calculations with other $\mathrm{Na}_{2} \mathrm{O}$ and $\mathrm{K}_{2} \mathrm{O}$ ratios resulted in the same six main element species (HSC-K25 and HSC-K75). The portion is shifted to higher and lower contents of $\mathrm{Na}$ and $\mathrm{K}$ correlating to the added amounts of alkali oxides (Fig. S4).

Furthermore, we tested calculations with extra addition of $2 \mathrm{~mol} \mathrm{SiO}_{2}$ as well as $2 \mathrm{~mol} \mathrm{SiO}_{2}$ and $1 \mathrm{~mol} \mathrm{Al}_{2} \mathrm{O}_{3}$ (data not shown). Phosphates species do not change and the content was quite similar. $\mathrm{KAlSi}_{2} \mathrm{O}_{6}$ and $\mathrm{KAlSi}_{3} \mathrm{O}_{8}$ were additionally formed by adding $2 \mathrm{~mol} \mathrm{SiO}_{2}$. Addition of $2 \mathrm{~mol} \mathrm{SiO}_{2}$ and $1 \mathrm{~mol} \mathrm{Al}_{2} \mathrm{O}_{3}$ increased the content of $\mathrm{Al}_{2} \mathrm{O}_{3} * \mathrm{SiO}_{2}$.

Finally, we can conclude the thermodynamic calculation of a simplified element species system shows that $\mathrm{Na}$ is preferably bonded in phosphate phases and $\mathrm{K}$ in silicates.

\section{Discussion}

\section{Relation between process reaction temperature and melting point of alkali additive}

Maximum $\mathrm{P}_{\mathrm{NAC} \text {,rel }}$ correlates very well with melting points of alkali sulfate in the phase diagram $\mathrm{Na}_{2} \mathrm{SO}_{4}-\mathrm{K}_{2} \mathrm{SO}_{4}$ by Rowe [26] (Table 4). The melting point of $3 \mathrm{Na}_{2} \mathrm{SO}_{4} \cdot \mathrm{K}_{2} \mathrm{SO}_{4}$ (comparable to series CT-K25) is the lowest with $823{ }^{\circ} \mathrm{C}$ in this phase system. The melting points increased monotonously with increasing mass fractions of $\mathrm{K}_{2} \mathrm{SO}_{4}$. It is $910{ }^{\circ} \mathrm{C}$ for $\mathrm{Na}_{2} \mathrm{SO}_{4} \cdot \mathrm{K}_{2} \mathrm{SO}_{4}$ (comparable to series CT-K50) and $1000{ }^{\circ} \mathrm{C}$ for $\mathrm{Na}_{2} \mathrm{SO}_{4} \cdot 3 \mathrm{~K}_{2} \mathrm{SO}_{4}$ (comparable to series CT-K75). These melting points are compared with reaction temperatures of the crucible trials series with high level of $\mathrm{P}_{\text {NAC,rel }} \geq 90 \%$. The reaction temperature is minimal $30{ }^{\circ} \mathrm{C}$ (series CT-Na) and maximally $80{ }^{\circ} \mathrm{C}$ (series CT-K100) above the respective melting points showing that melting of the additive significantly supports the reaction between additive and crystalline P-phases. However, the increase of $\mathrm{P}_{\mathrm{NAC}, \text { rel }}$ already starts below the melting points [15] indicating that solid phase reactions between phosphate phases in SSA and additives $\left(\mathrm{Na}_{2} \mathrm{SO}_{4}, \mathrm{~K}_{2} \mathrm{SO}_{4}\right)$ take place. This is supported by thermogravimetric experiments suggesting that decomposition of $\mathrm{Na}_{2} \mathrm{SO}_{4}$ already starts at approx. $600{ }^{\circ} \mathrm{C}$ under reducing conditions producing sodium oxide that reacts with the crystalline P-phases [41].

\section{Preparation of mixtures of additive}

A further challenge was to ensure that the mixture of $\mathrm{Na}_{2} \mathrm{SO}_{4}$ and $\mathrm{K}_{2} \mathrm{SO}_{4}$ reacts as mixture with the respective melting points (Table 4) and not as individual phases. To ensure proper mixing and activating of the $\mathrm{K}_{2} \mathrm{SO}_{4}$ fraction, additive mixtures were milled and preheated at $600{ }^{\circ} \mathrm{C}$ for the laboratory-scale experiments. The results of the pilot-scale trials show that this preheating is not necessary. The samples L-5 to L-7 represent the mixture L-K50 and have comparable $\mathrm{P}_{\mathrm{NAC} \text {,rel }}$ as samples $\mathrm{L}-1$ and $\mathrm{L}-2$ representing mixture $\mathrm{L}-\mathrm{Na}$ (Fig. 4). Thus, the $\mathrm{K}_{2} \mathrm{SO}_{4}$ fraction of the additive took part in the reaction with the phosphate phases presumably after forming an eutectic melt together with $\mathrm{Na}_{2} \mathrm{SO}_{4}$.

\section{Comparison of laboratory-scale and pilot-scale trial for phosphorus availability}

The lower values of $\mathrm{P}_{\mathrm{NAC} \text {,rel }}$ in pilot-scale trial (Fig. 4) compared to corresponding laboratory-scale experiments (Fig. 1) are based on the use of sulfates as additives. Comparable results with $\mathrm{Na}_{2} \mathrm{SO}_{4}$ as additive were observed in demonstration-scale trials that achieved a $\mathrm{P}_{\mathrm{NAC}, \text { rel }}$ of maximal 80\% [10] and $\mathrm{P}_{\mathrm{NAC} \text {,rel }}$ of 75\% [15]. Phosphorus was nearly completely extractable with neutral ammonium citrate in case pilot-scale trials were conducted with $\mathrm{Na}_{2} \mathrm{CO}_{3}$ $\left(\mathrm{P}_{\mathrm{NAC}, \text { rel }}>90 \%\right)$ instead of $\mathrm{Na}_{2} \mathrm{SO}_{4}[16,17]$. This implies that the choice of the type of additive has a strong influence on the success of thermochemical reaction in the rotary kiln (pilot-scale trials). Carbonates should be preferred.

Furthermore, $\mathrm{P}_{\mathrm{NAC}, \text { rel }}$ in the pilot-scale trials declined with increasing $\mathrm{K}$ content (L- 8 to L-12) as it was observed after feeding the material mixture L-K75 (Fig. 4). We assume that the reaction temperature in the kiln was not high enough to force reaction between SSA and K-rich alkali sulfate mixtures. Laboratory-scale experiments (CT-K75) postulate that $1000{ }^{\circ} \mathrm{C}$ is sufficient to transform all phosphate phases to calcium alkali phosphate in case an additive containing $75 \mathrm{~mol} \% \mathrm{~K}_{2} \mathrm{SO}_{4}$ and $25 \mathrm{~mol} \% \mathrm{Na}_{2} \mathrm{SO}_{4}$ is used 
(Fig. 1). The kiln set up temperature was $1000{ }^{\circ} \mathrm{C}$ but the measured temperature in the material bed was $950-970{ }^{\circ} \mathrm{C}$. Thus, this material bed temperature was too low to promote reactions between SSA and K-rich sulfates in L-K75.

\section{Formation of $(\mathrm{Ca}, \mathrm{Mg}) \mathrm{NaPO}_{4}$ or $\mathrm{CaNaPO}_{4}$}

Crystalline phase analysis and $\mathrm{P}_{\mathrm{NAC} \text {,rel }}$ confirmed that low plant available phosphate phases in SSA were completely transformed to highly plant available $(\mathrm{Ca}, \mathrm{Mg}) \mathrm{NaPO}_{4}$ or $\mathrm{Ca}(\mathrm{Na}, \mathrm{K}) \mathrm{PO}_{4}$ in laboratory-scale experiments (Table 3 ). Previous studies postulate that $\mathrm{CaNaPO}_{4}$ [14] and the associated phase $2 \mathrm{CaNaPO}_{4} * \mathrm{Ca}_{2} \mathrm{SiO}_{4}$ [16] are main compounds after thermochemical treatment of SSA with $\mathrm{Na}_{2} \mathrm{SO}_{4}$ or $\mathrm{Na}_{2} \mathrm{CO}_{3}$. The presence of $2 \mathrm{CaNaPO}_{4} * \mathrm{Ca}_{2} \mathrm{SiO}_{4}$ can be expected in case of high calcium mass fractions e.g. by dosing of $\mathrm{CaCO}_{3}[16]$.

Steckenmesser et al. [19] identified also a magnesium containing calcium alkali phosphate $(\mathrm{Ca}, \mathrm{Mg}) \mathrm{NaPO}_{4}$. This phase can be formed in case of low ratio of Ca to $\mathrm{P}$ [19]. In our study, a higher ratio of $\mathrm{Ca}$ to $\mathrm{P}$ (Table 1) compared to Steckenmesser et al. [19] is given indicating that the inclusion of magnesium in the phosphate phase was not forced by a shortage in Ca supply.

In our case, the process conditions and composition of additives presumably play a major role for the formation of $(\mathrm{Ca}, \mathrm{Mg}) \mathrm{NaPO}_{4}$. The pilot-scale and corresponding laboratory-scale experiments resulted in different P-phases at similar chemical compositions. The product samples L-1 and L-2 of pilot-scale trial (Table S1) contain mainly (Ca, Mg) $\mathrm{NaPO}_{4}$, whereas $\mathrm{CaNaPO}_{4}$ is dominant in the corresponding laboratory-scale experiment sample CT-Na-1000 (Table 3).

Furthermore, the evaluation of crystalline phase composition in samples CT-K50-1000 (Table 3) indicates that $(\mathrm{Ca}, \mathrm{Mg}) \mathrm{NaPO}_{4}$ is formed preferentially instead of $\mathrm{CaNaPO}_{4}$ using K-containing additives (Fig. 2). Presumably, $\mathrm{K}$ is also incorporated in $\mathrm{CaNaPO}_{4}$ and $(\mathrm{Ca}, \mathrm{Mg}) \mathrm{NaPO}_{4}$ indicated by an extraction of $\mathrm{K}$ by neutral ammonium citrate solution (Table 2). $\mathrm{CaNaPO}_{4}$ can incorporate up to $10 \mathrm{~mol} \% \mathrm{~K}$ without crystal phase transition [42]. Presumably, (Ca,Mg) $\mathrm{NaPO}_{4}$ can incorporation similar amounts.

Formation of $(\mathrm{Ca}, \mathrm{Mg}) \mathrm{NaPO}_{4}$ is connected to incomplete phase transition from whitlockite to calcium alkali phosphate in pilot-scale trial and in case of using K-containing additives in laboratory-scale experiments. It can be assumed that $(\mathrm{Ca}, \mathrm{Mg}) \mathrm{NaPO}_{4}$ is an intermediate phase between $\mathrm{Mg}$ whitlockite $(\mathrm{Ca}, \mathrm{Mg})_{3}\left(\mathrm{PO}_{4}\right)_{2}$ and $\mathrm{CaNaPO}_{4}$ [15]. $\mathrm{Mg}$ can substitute up to $15 \%$ of $\mathrm{Ca}$ in whitlockite [43].

\section{Incorporation of K preferred in silicates}

The additives $\mathrm{Na}_{2} \mathrm{SO}_{4}$ and $\mathrm{K}_{2} \mathrm{SO}_{4}$ react with silicates as well as with phosphates from SSA. More precisely, silicates are formed before calcium alkali phosphates [14]. In case only one alkali sulfate is used as additive, the order of formation is irrelevant. Addition of $\mathrm{Na}_{2} \mathrm{SO}_{4}$ or $\mathrm{K}_{2} \mathrm{SO}_{4}$ is resulting in the formation of $\mathrm{CaNaPO}_{4}$ or $\mathrm{CaKPO}_{4}$, respectively [10]. In case of using mixtures of both additives, the ratio of alkalis in additives and in the formed phosphates are different [44]. Calcium alkali phosphates contain less $\mathrm{K}$ as expected (Table 2). Samples CT-K25-1000 and CT-K50-1000 contains P-phases with low amounts of $\mathrm{K}$ (Table 2) despite of the addition of $\mathrm{K}_{2} \mathrm{SO}_{4}(25 \mathrm{~mol} \%$ or $50 \mathrm{~mol} \%)$. In contrast, $\mathrm{K}$ containing silicates $\left((\mathrm{Na}, \mathrm{K}) \mathrm{AlSiO}_{4}, \mathrm{KAlSiO}_{4}\right.$ and $\mathrm{KAlSi}_{2} \mathrm{O}_{6}$ ) are dominant in these samples (Table 3). Apparently, formation of $\mathrm{K}$ silicates is preferred compared to $\mathrm{Na}$ silicates. Thus, calcium alkali phosphates can first incorporate remaining $\mathrm{K}$ into the calcium alkali phosphates after finishing of formation of $\mathrm{K}$ containing silicates. This led to the formation of $\mathrm{K}$ containing calcium alkali phosphates only in case of addition of high amounts of $\mathrm{K}_{2} \mathrm{SO}_{4}$ (CT-K751050) (Table 2). Thus, CT-K75-1050 can be postulate as a promising PK-fertilizer which contains $88 \%$ of $\mathrm{P}$ and $35 \%$ of $\mathrm{K}$ extractable in neutral ammonium citrate (Figs. 1 and 6). The required reaction temperature of $1050{ }^{\circ} \mathrm{C}$ for production of this PK-fertilizers is feasible for an industrial-scale plant.

If $\mathrm{Na}$ or $\mathrm{K}$ is preferably incorporated in phosphates $\left[\mathrm{Ca}(\mathrm{Na}, \mathrm{K}) \mathrm{PO}_{4}\right]$ could not be deduced by laboratory-scale experiments. Synthesis of $\mathrm{K}$ containing $\mathrm{Ca}(\mathrm{Na}, \mathrm{K}) \mathrm{PO}_{4}$ indicates that $\mathrm{Na}$ is preferably incorporated in $\mathrm{Ca}(\mathrm{Na}, \mathrm{K})$ $\mathrm{PO}_{4}$ [37]. This supports the preferred formation Na-rich $\mathrm{Ca}(\mathrm{Na}, \mathrm{K}) \mathrm{PO}_{4}$.

The thermodynamic calculation confirmed that $\mathrm{K}$ is preferably incorporated in silicates $(\mathrm{Na}, \mathrm{K}) \mathrm{AlSiO}_{4}$ and predict that $\mathrm{Na}$ is preferably incorporated in $\mathrm{Ca}(\mathrm{Na}, \mathrm{K}) \mathrm{PO}_{4}$.

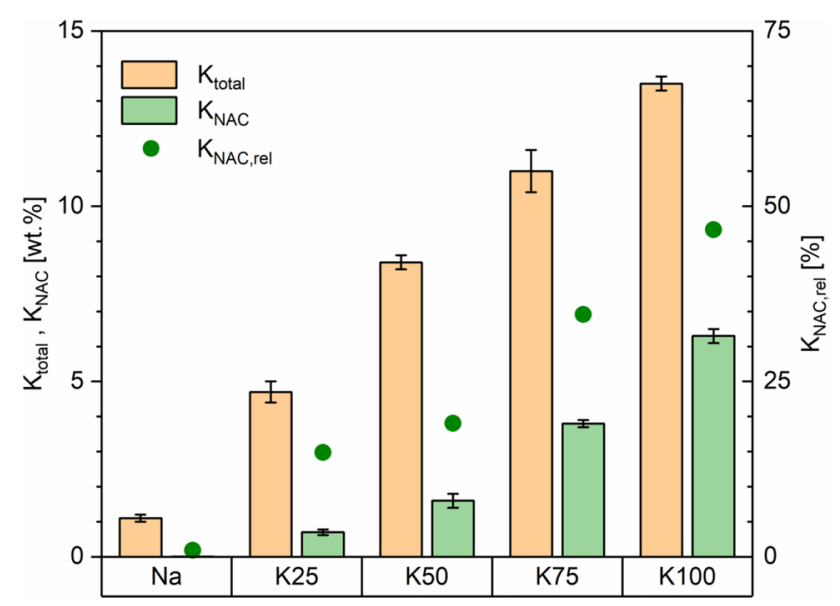

Fig. 6 Extractable $\mathrm{K}$ in NAC is displayed as absolute $\left(\mathrm{K}_{\mathrm{NAC}}\right)$ and relative values $\left(\mathrm{K}_{\mathrm{NAC}, \text { rel }}\right)$ for samples CT-Na-1000, CT-K25-1000, CT-K50-1000, CT-K75-1050 and CT-K100-1150. $\mathrm{K}_{\mathrm{NAC} \text {,rel }}$ is defined as the ratio of extractable potassium (Table 2) and total amount of potassium $\left(\mathrm{K}_{\text {total }}\right.$, Table 1$)$ in one sample 
Nevertheless, the temporal progression (first silicate reaction, later phosphate reaction) could not be illustrated by thermodynamic calculation. For this reason, $\mathrm{CaKPO}_{4}$ is available in thermodynamic calculation (Fig. S4 and Fig. 5) but is not present in corresponding laboratory-scale experiments CT-K25 and CT-K50 (Table 3).

The preferred incorporation of $\mathrm{K}$ in silicates could be a drawback to produce PK-fertilizers. Thermochemical products containing $\mathrm{CaNaPO}_{4}$ are known to have high plant availability of $\mathrm{P}$ comparable to struvite and triple super phosphate $[16,17]$.

The plant availability of $\mathrm{K}$ cannot be certainly determined with neutral ammonium citrate solution since it is a non-standard extraction method for K-fertilizers. Other non-standard extraction methods (e.g., hydrochloric acid $(0.5 \mathrm{~mol} / \mathrm{L})$ and $\left.\mathrm{HNO}_{3}(\mathrm{pH} 5)\right)$ used for extraction of K-silicates without correlation to plant growth tests $[45,46]$ but were not tested for K containing phosphate fertilizers. Only, water solubility is a standard method for $\mathrm{K}$ which is certified for K-fertilizers containing $\mathrm{KCl}$ and $\mathrm{K}_{2} \mathrm{SO}_{4}$ [29].

Calcium alkali phosphates are a new category for PKfertilizers which are not soluble in water [11]. Previous extraction and plant availability tests of K-containing calcium alkali phosphates are focus on phosphorus [23, 24] but also reported a complete extraction of $\mathrm{K}$ in in citric acid [23]. Data for extraction of $\mathrm{K}$ in neutral ammonium citrate are not reported previously.

Potassium bonded in $\mathrm{Ca}(\mathrm{Na}, \mathrm{K}) \mathrm{PO}_{4}$ is most likely plant available because $\mathrm{K}$ is extracted in neutral ammonium citrate (Table 2 and Fig. 6) and citric acid solution [23]. Alkali bonded in silicates are not extractable with neutral ammonium citrate solution and have a very low dissolution rate [45] and presumably less plant available. This is in line with finding by Santos et al. [47]. They measured a low extractability of $\mathrm{K}$ in citric acid for rocks containing $\mathrm{KAlSi}_{3} \mathrm{O}_{8}$. Franca et al. [48] postulate kalsilite as a slow release fertilizer but they investigated water containing kalsilite $\left(\mathrm{KAlSiO}_{4} * 1.5 \mathrm{H}_{2} \mathrm{O}\right.$ ) and not the water free phase $\mathrm{KAlSiO}_{4}$. Thus, we conclude the $\mathrm{K}$ bonded in silicates $\left(\mathrm{KAlSiO}_{4}\right.$, $\left.(\mathrm{Na}, \mathrm{K}) \mathrm{AlSiO}_{4}, \mathrm{KAlSi}_{2} \mathrm{O}_{6}\right)$ in our samples is poorly plant available and $\mathrm{K}$ bonded in calcium alkali phosphates are predicted to be plant available.

\section{Conclusions}

Our target was to show that $\mathrm{K}$ containing alkali sulfates are suitable to form highly plant available $\mathrm{K}$ and $\mathrm{P}$ products after thermochemical treatment of sewage sludge ash. The sufficient reaction temperature of thermochemical treatment is strongly connected to the melting point of used alkali sulfates. Thus, $\mathrm{K}_{2} \mathrm{SO}_{4}$ is unsuitable for thermochemical treatment due to its high melting point. If it is mixed with
$\mathrm{Na}_{2} \mathrm{SO}_{4}$ the reaction temperature is decreasing according to the eutectic melting point. $25 \mathrm{~mol} \%$ of $\mathrm{Na}_{2} \mathrm{SO}_{4}$ in additive mixture is enough to reduce the melting temperature to an economically suitable reaction temperature of $1050{ }^{\circ} \mathrm{C}$.

Potassium is preferably incorporated in the silicate structure instead of calcium alkali phosphate phase. This could be deduced by laboratory-scale and pilot-scale experiments as well as by thermodynamic calculations. The formed highly plant available $\mathrm{P}$ phase $(\mathrm{Ca}, \mathrm{Mg})(\mathrm{Na}, \mathrm{K}) \mathrm{PO}_{4}$ contains less $\mathrm{K}$ as expected. The bonded $\mathrm{K}$ in silicates is assumed to be poorly plant available and will be investigated in ongoing studies. Thus, the produced PK-fertilizer is highly plant available for $\mathrm{P}$ as well as for $\mathrm{K}$ bonded in phosphate phases.

Supplementary Information The online version contains supplementary material available at https://doi.org/10.1007/s10163-021-01288-3.

Acknowledgements The experimental work was carried out in the framework of the project ASHES, funded by the German Federal Ministry of Education and Research (BMBF, grand number 031A288) and evaluated in the framework of the project R-Rhenania, funded by BMBF (grand number 02WPR1547). The reference material BAMD826-1 was provided courtesy by Sebastian Recknagel (BAM division 1.6).

Funding Open Access funding enabled and organized by Projekt DEAL.

Open Access This article is licensed under a Creative Commons Attribution 4.0 International License, which permits use, sharing, adaptation, distribution and reproduction in any medium or format, as long as you give appropriate credit to the original author(s) and the source, provide a link to the Creative Commons licence, and indicate if changes were made. The images or other third party material in this article are included in the article's Creative Commons licence, unless indicated otherwise in a credit line to the material. If material is not included in the article's Creative Commons licence and your intended use is not permitted by statutory regulation or exceeds the permitted use, you will need to obtain permission directly from the copyright holder. To view a copy of this licence, visit http://creativecommons.org/licenses/by/4.0/.

\section{References}

1. EC (2015) Report on critical raw materials for the EU-non-critical raw materials profiles. https://ec.europa.eu/docsroom/documents/ 7422/attachments/1/translations/en/renditions/native. Accessed 1 Oct 2020

2. USGS (2020) phosphate rock - Annual Publications. https://pubs. usgs.gov/periodicals/mcs2020/mcs2020-phosphate.pdf. Accessed 1 Oct 2020

3. IFASTAT (2020) Phosphate products: production and trade tables by region. https://www.ifastat.org/supply/Phosphate\%20Products/ Phosphate\%20Rock. Accessed 1 Oct 2020

4. Smol M (2019) The importance of sustainable phosphorus management in the circular economy (CE) model: the Polish case study. J Mater Cycles Waste Manag 21(2):227-238. https://doi. org/10.1007/s10163-018-0794-6

5. Krüger O, Adam C (2015) Recovery potential of German sewage sludge ash. Waste Manag 45:400-406. https://doi.org/10.1016/j. wasman.2015.01.025 
6. Kasina M, Wendorff-Belon M, Kowalski PR, Michalik M (2019) Characterization of incineration residues from wastewater treatment plant in Polish city: a future waste based source of valuable elements? J Mater Cycles Waste Manag 21(4):885-896. https:// doi.org/10.1007/s10163-019-00845-1

7. Industrieverband Agrar (2018) Wichtige Zahlen DüngemittelProduktion-Markt-Landwirtschaft 2017-2018. https://www.iva. $\mathrm{de} /$ sites/default/files/benutzer/\%25uid/publikationen/wichtige_ zahlen_2017-2018.pdf. Accessed 1 Oct 2020 (in German)

8. VVEA (2016) Verordnung über die Vermeidung und die Entsorgung von Abfällen (VVEA). Switzerland. https://www.fedlex. admin.ch/eli/cc/2015/891/de. Accessed 1 Oct 2020 (in German)

9. AbfKlär V (2017) Verordnung über die Verwertung von Klärschlamm, Klärschlammgemisch und Klärschlammkompost (Klärschlammverordnung-AbfKlärV) 27.09.2017. Germany. https:// www.gesetze-im-internet.de/abfkl_rv_2017/BJNR346510017. html. Accessed 1 Oct 2020 (in German)

10. Herzel H, Krüger O, Hermann L, Adam C (2016) Sewage sludge ash: a promising secondary phosphorus source for fertilizer production. Sci Tot Environ 542:1136-1143. https://doi.org/10. 1016/j.scitotenv.2015.08.059

11. Kratz S, Vogel C, Adam C (2019) Agronomic performance of $\mathrm{P}$ recycling fertilizers and methods to predict it: a review. Nutr Cycl Agroecosyst 115(1):1-39. https://doi.org/10.1007/ s10705-019-10010-7

12. Peplinski B, Adam C, Michaelis M, Kley G, Emmerling F, Simon FG (2009) Reaction sequences in the thermo-chemical treatment of sewage sludge ashes revealed by X-ray powder diffraction: a contribution to the European project SUSAN Eleventh European Powder Diffraction Conference. De Gruyter, Berlin, pp 459-464. https://doi.org/10.1524/9783486992588-072

13. Nanzer S, Oberson A, Huthwelker T, Eggenberger U, Frossard E (2014) The Molecular environment of phosphorus in sewage sludge ash: implications for bioavailability. J Environ Qual 43(3):1050-1060. https://doi.org/10.2134/jeq2013.05.0202

14. Stemann J, Peplinski B, Adam C (2015) Thermochemical treatment of sewage sludge ash with sodium salt additives for phosphorus fertilizer production: analysis of underlying chemical reactions. Waste Manag 45:385-390. https://doi.org/10.1016/j. wasman.2015.07.029

15. Herzel H, Stemann J, Simon S, Adam C (2021) Comparison of thermochemical treatment of sewage sludge ash with sodium sulphate in laboratory-scale and pilot-scale experiments. Int J Environ Sci Technol. https://doi.org/10.1007/s13762-021-03252-y

16. Severin M, Breuer J, Rex M, Stemann J, Adam C, Van den Weghe H, Kücke M (2014) Phosphate fertiliser value of heat treated sewage sludge ash. Plant Soil Environ 60(12):555-561

17. Vogel C, Rivard C, Wilken V, Muskolus A, Adam C (2018) Performance of secondary P-fertilizers in pot experiments analyzed by phosphorus X-ray absorption near-edge structure (XANES) spectroscopy. Ambio 47(1):62-72. https://doi.org/10.1007/ s13280-017-0973-z

18. Kabbe C (2014) Challage and opportunities for P recovery and recycling from sewage sludge in Europe. In: Workshop-Phosphor für die Landwirtschaft-Strategien für eine endliche Ressource, 11 June 2014

19. Steckenmesser D, Vogel C, Adam C, Steffens D (2017) Effect of various types of thermochemical processing of sewage sludges on phosphorus speciation, solubility, and fertilization performance. Waste Manag 62:194-203. https://doi.org/10.1016/j.wasman. 2017.02.019

20. Steckenmesser D, Vogel C, Steffens D (2019) Medium-scale plant experiment of sewage sludge-based phosphorus fertilizers from large-scale thermal processing. Commun Soil Sci Plant Anal 50(19):2469-2481. https://doi.org/10.1080/00103624.2019.16673 73
21. Steckenmesser D, Vogel C, Herzel H, Félix R, Adam C, Steffens D (2021) Thermal treatment of sewage sludge for phosphorus fertilizer production: a model experiment. J Plant Nutr. Accepted

22. Alkemper J, Fuess H (1998) The crystal structures of NaMgPO4, $\mathrm{Na} 2 \mathrm{CaMg}(\mathrm{PO} 4) 2$ and $\mathrm{Na} 18 \mathrm{Ca} 13 \mathrm{Mg} 5(\mathrm{PO} 4) 18$ : new examples for glaserite related structures. Zeitschrift für Kristallographie Cryst Mater 213(5):282-287. https://doi.org/10.1524/zkri.1998.213.5. 282

23. Gunawardane RP, Annersten H (1987) Fertilizer from eppawela apatite: conversion using alkali hydroxide and quartz. J Natl Sci Found 15(2):117-132. https://doi.org/10.4038/jnsfsr.v15i2.8285

24. Nakamura S, Kanda T, Imai T, Sawadogo J, Nagumo F (2019) Solubility and application effects of African low-grade phosphate rock calcinated with potassium carbonate. Soil Sci Plant Nutr 65(3):267-273. https://doi.org/10.1080/00380768.2019.1598236

25. Kótai L, Szépvölgyi J, Bozi J, Gács I, Bálin S, Gomory A, Angyal A, Balogh J, Zhibin L, Chen M, Wang C, Chen B (2011) An integrated waste-free biomass utilization system for an increased productivity of biofuel and bioenergy. Biodiesel Feedstocks Process Technol. https://doi.org/10.5772/25544

26. Rowe JJ, Morey GW, Zen CS (1972) The quinary reciprocal salt system $\mathrm{Na}, \mathrm{K}, \mathrm{Mg}, \mathrm{Ca} / \mathrm{Cl}, \mathrm{SO}_{4}$ : a review of the literature with new data. Geol Surv Prof 741. https://pubs.er.usgs.gov/publication/ pp741

27. Krüger O, Grabner A, Adam C (2014) Complete survey of german sewage sludge ash. Environ Sci Technol 48(20):11811-11818. https://doi.org/10.1021/es502766x

28. Krüger O, Adam C (2014) Monitoring von Klärschlammmonoverbrennungsaschen hinsichtlich ihrer Zusammensetzung zur Ermittlung ihrer Rohstoffrückgewinnungspotentiale und zur Erstellung von Referenzmaterial für die Überwachungsanalytik, Forschungskennzahl (UFO-PLAN) 371133 321. Umweltbundesamt, Germany. https://www.umweltbundesamt.de/publikationen/monit oring-von-klaerschlammmonoverbrennungsaschen. Accessed 1 Oct 2020 (in German)

29. EU (2003) Regulation (EC) No 2003/2003 of the European Parliament and of the Council of 13 October 2003 Relating to Fertilizers. EU, Brussels

30. Dybczynaski R, Polkowska-Motrenko H, Samczynaski Z, Szopa Z (1991) Two New polish geological-environmental reference materials: apatite concentrate (CTA-AC-1) and fine fly ash (CTA-FFA-1). Geostand Newsl 15(2):163-185. https://doi.org/ 10.1111/j.1751-908X.1991.tb00110.x

31. BAM (2016) Reference materials certificates and reports slags and dusts. https://rrr.bam.de/RRR/Navigation/EN/ReferenceMaterials/RM-Certificates-reports/Iron-and-steel/Slags-dusts/ rm-slags-dusts.html. Accessed 1 Oct 2020

32. Crystallin Impact (2018) Match! version 3.6 [Computer software]. Crystal Impact GbR, Bonn

33. ICDD (2003) International centre for diffraction data PDF-2 (Database). ICDD, Newtown Square

34. Gottschalk PG, Dunn JR (2005) The five-parameter logistic: a characterization and comparison with the four-parameter logistic. Anal Biochem 343(1):54-65. https://doi.org/10.1016/j.ab.2005. 04.035

35. Mahieux PY, Aubert JE, Cyr M, Coutand M, Husson B (2010) Quantitative mineralogical composition of complex mineral wastes: contribution of the Rietveld method. Waste Manag 30(3):378-388. https://doi.org/10.1016/j.wasman.2009.10.023

36. Orlov NK, Evdokimov PV, Milkin PA, Garshev AV, Putlayev VI, Grebenev VV, Günster J (2019) Phase equilibria in $\mathrm{CaNaPO}_{4}-\mathrm{CaKPO}_{4}$ system and their influence on formation of bioceramics based on mixed Ca-K-Na phosphates. J Eur Ceram Soc 39(16):5410-5422. https://doi.org/10.1016/j.jeurceramsoc. 2019.07.044 
37. Herzel H, Grevel K-D, Emmerling F, Dachs E, Benisek A, Adam C, Majzlan J (2020) Thermodynamic properties of calcium alkali phosphates $\mathrm{Ca}(\mathrm{Na}, \mathrm{K}) \mathrm{PO}_{4}$. J Mater Sci 55(20):8477-8490. https:// doi.org/10.1007/s10853-020-04615-5

38. Ando J, Matsuno S (1968) $\mathrm{Ca}_{3}\left(\mathrm{PO}_{4}\right)_{2}-\mathrm{CaNaPO}_{4}$ System. B Chem Soc Jpn 41(2):342-347

39. Roine A (2007) HSC chemistry for windows, Outotec Research Oy, Version 6.12

40. Robie RA, Hemingway BS (1995) Thermodynamic properties of minerals and related substances at $298.15 \mathrm{~K}$ and 1 bar $\left(10^{\wedge} 5\right.$ pascals) pressure and at higher temperatures. US Geol Surv Bull. https://doi.org/10.3133/b2131

41. Vogel C, Krüger O, Adam C (2016) Thermochemical treatment of sewage sludge ash with sodium additives under reducing conditions analyzed by thermogravimetry. J Therm Anal Calorim 123(2):1045-1051. https://doi.org/10.1007/s10973-015-5016-Z

42. Znamierowska T (1982) Uklad $\mathrm{Ca}_{3}(\mathrm{PO} 4)_{2}-\mathrm{CaNaPO}_{4}-\mathrm{CaKPO}_{4}$. Zesz Nauk Politech Slask Ser 709(100):35-56

43. Schroeder LW, Dickens B, Brown WE (1977) Crystallographic studies of the role of $\mathrm{Mg}$ as a stabilizing impurity in $\beta-\mathrm{Ca}_{3}(\mathrm{PO} 4)_{2}$. II. Refinement of Mg-containing $\beta-\mathrm{Ca}_{3}(\mathrm{PO} 4)_{2}$. J Solid State Chem 22(3):253-262. https://doi.org/10.1016/0022-4596(77)90002-0

44. Herzel H, Dombinov V, Vogel C, Willbold S, Vettorazzi Levandowski G, Meiller M, Müller F, Zang JW, da Fonseca-Zang WA, Jablonowski ND, Schrey SD, Adam C (2020) Soybean fertilized by P-phases from Bagasse-based materials: P-extraction procedures, diffusive gradients in thin films (DGT), and X-ray diffraction analysis (XRD). Agronomy 10(6):895. https://doi.org/10. 3390/agronomy 10060895

45. Ciceri D, de Oliveira M, Allanore A (2017) Potassium fertilizer via hydrothermal alteration of K-feldspar ore. Green Chem 19(21):5187-5202. https://doi.org/10.1039/C7GC02633A

46. Zhao Q, Li X, Wu Q, Liu Y, Lyu Y (2020) Evolution of mineral phases and microstructure of high efficiency $\mathrm{Si}-\mathrm{Ca}-\mathrm{K}-\mathrm{Mg}$ fertilizer prepared by water-insoluble K-feldspar. J Sol-Gel Sci Technol 94(1):3-10. https://doi.org/10.1007/s 10971-020-05284-1

47. Santos WO, Mattiello EM, Vergutz L, Costa RF (2016) Production and evaluation of potassium fertilizers from silicate rock. J Plant Nutr Soil Sci 179(4):547-556. https://doi.org/10.1002/jpln.20150 0484

48. França AA, Schultz J, Borges R, Wypych F, Mangrich AS (2017) Rice husk ash as raw material for the synthesis of silicon and potassium slow-release fertilizer. J Braz Chem Soc 28:2211-2217

Publisher's Note Springer Nature remains neutral with regard to jurisdictional claims in published maps and institutional affiliations. 